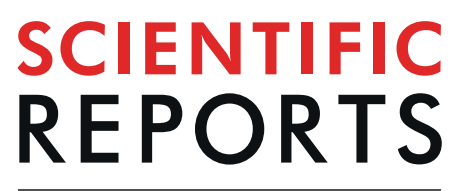

natureresearch

Received: 30 January 2019

Accepted: 19 July 2019

Published online: 29 July 2019

\section{Synchrony of nitrogen supply and crop demand are driven via high maize density in maize/pea strip intercropping}

\author{
Zhilong Fan ${ }^{1,2}$, Yanhua Zhao ${ }^{1,3}$, Qiang Chai ${ }^{1,2}$, Cai Zhao ${ }^{1,2}$, Aizhong Yu ${ }^{1,2}$, Jeffrey A. Coulter $\mathbb{D}^{4}$, \\ Yantai Gan $\mathbb{1}^{5}$ \& Weidong $\mathrm{Cao}^{6}$
}

Cereal density may influence the balance between nitrogen ( $\mathrm{N}$ ) supply and crop $\mathrm{N}$ demand in cereal/ legume intercrop systems. The effect of maize (Zea mays $\mathrm{L}$.) plant density on $\mathrm{N}$ utilization and $\mathrm{N}$ fertilizer supply in maize/pea (Pisum sativum L.) strip intercropping was evaluated in a field study with sole maize, sole pea, and intercropped maize/pea with three maize densities (D1, 45,000 plants ha $^{-1}$; D2, 52,500 plants ha ${ }^{-1}$; D3, 60,000 plants ha ${ }^{-1}$ ) and two $\mathrm{N}$ treatments (N0, $0 \mathrm{~kg} \mathrm{~N} \mathrm{ha}^{-1} ; \mathrm{N1}, 450 \mathrm{~kg} \mathrm{~N}$ $\mathrm{ha}^{-1}$ for maize and $225 \mathrm{~kg} \mathrm{~N} \mathrm{ha}^{-1}$ for pea). Soil mineral $\mathrm{N}$ in intercropped strips decreased with increased maize density. Increased maize density decreased $\mathrm{N}$ accumulation for intercropped pea but increased it for maize and the sum of both intercrops. The land equivalent ratio for grain yield (LER grain) showed a 24-30\% advantage for intercrops than corresponding sole crops, and was greater with D3 than D1 and D2. Maize/pea intercropping had 4-113\% greater nitrogen use efficiency (NUE) than sole maize, which was enhanced with increased maize density. Increasing maize density improved the synchrony of $\mathrm{N}$ supply and crop demand in maize/pea strip intercropping.

Nitrogen $(\mathrm{N})$ is a major plant nutrient, that is typically the most limiting in agriculture and plays a crucial role in the proper functioning of cropping systems $\mathrm{s}^{1,2}$. Synthetic fertilizers and biological $\mathrm{N}_{2}$ fixation by legumes are the most important sources of $\mathrm{N}^{3,4}$. Biological $\mathrm{N}_{2}$ fixation by legumes is more renewable and environmentally friendly than application of $\mathrm{N}$ fertilizer ${ }^{5}$. In general, legume-based cropping systems are more sustainable than fertilizer-based systems ${ }^{6}$. Cereal/legume intercropping systems are utilized worldwide for food and feed production due to the facilitative interactions of intercrops and biological $\mathrm{N}_{2}$ fixation ${ }^{7}$. The substantial complementarities in the use of $\mathrm{N}$ resources between intercropped legumes and cereals has been verified in several studies ${ }^{8-10}$. Cereal/legume intercropping may sustain the yield of both crops under low $\mathrm{N}$ application ${ }^{11}$. Unfortunately, in China, intercropping has been developed using intensive farming systems with high levels of inputs, such as $\mathrm{N}$ fertilizer, to produce high yields ${ }^{12}$. The high levels of inputs with inefficient $\mathrm{N}$ use result in a large portion of the $\mathrm{N}$ applied being lost to the environment through gaseous losses and leaching ${ }^{13}$.

A major cause of inefficient use of $\mathrm{N}$ fertilizer and many environmental hazards associated with excess $\mathrm{N}$ in the biosphere is the asynchrony between the $\mathrm{N}$ supply and crop demand ${ }^{6}$. Fertilizer $\mathrm{N}$ use is inefficient in most cropping systems, with only about half of the applied $\mathrm{N}$ taken up by crops during the growing season ${ }^{14}$. The uncertainty faced by famers in determining fertilizer application rates includes not knowing the existing supply of $\mathrm{N}$ available in the soil as well as not being able to predict the $\mathrm{N}$ demand of the crop ${ }^{15}$. Soil $\mathrm{N}$ supply is often ignored when fertilizer rates are determined ${ }^{16}$. Fertilizer rates should be based on eliminating uncertainties in soil $\mathrm{N}$ supply and crop $\mathrm{N}$ demand. Eliminating the uncertainty of the soil $\mathrm{N}$ supply would reduce average $\mathrm{N}$ rates

${ }^{1}$ Gansu Provincial Key Laboratory of Arid land Crop Science, Lanzhou, 730070, China. ${ }^{2}$ The Faculty of Agronomy, Gansu Agricultural University, Lanzhou, 730070, China. ${ }^{3}$ College of Resources and Environmental Sciences, Gansu Agricultural University, Lanzhou, 730070, China. ${ }^{4}$ Department of Agronomy and Plant Genetics, University of Minnesota, St. Paul, MN, 55108, USA. ${ }^{5}$ Agriculture and Agri-Food Canada, Swift Current, SK, S9H 3X2, Canada. ${ }^{6}$ Key Laboratory of Plant Nutrition and Fertilizer, Ministry of Agriculture and Rural Affairs/Institute of Agricultural Resources and Regional Planning, Chinese Academy of Agricultural Sciences, Beijing, 100081, China. Correspondence and requests for materials should be addressed to Q.C. (email: chaiq@gsau.edu.cn) orW.C. (email: caoweidong@caas.cn) 

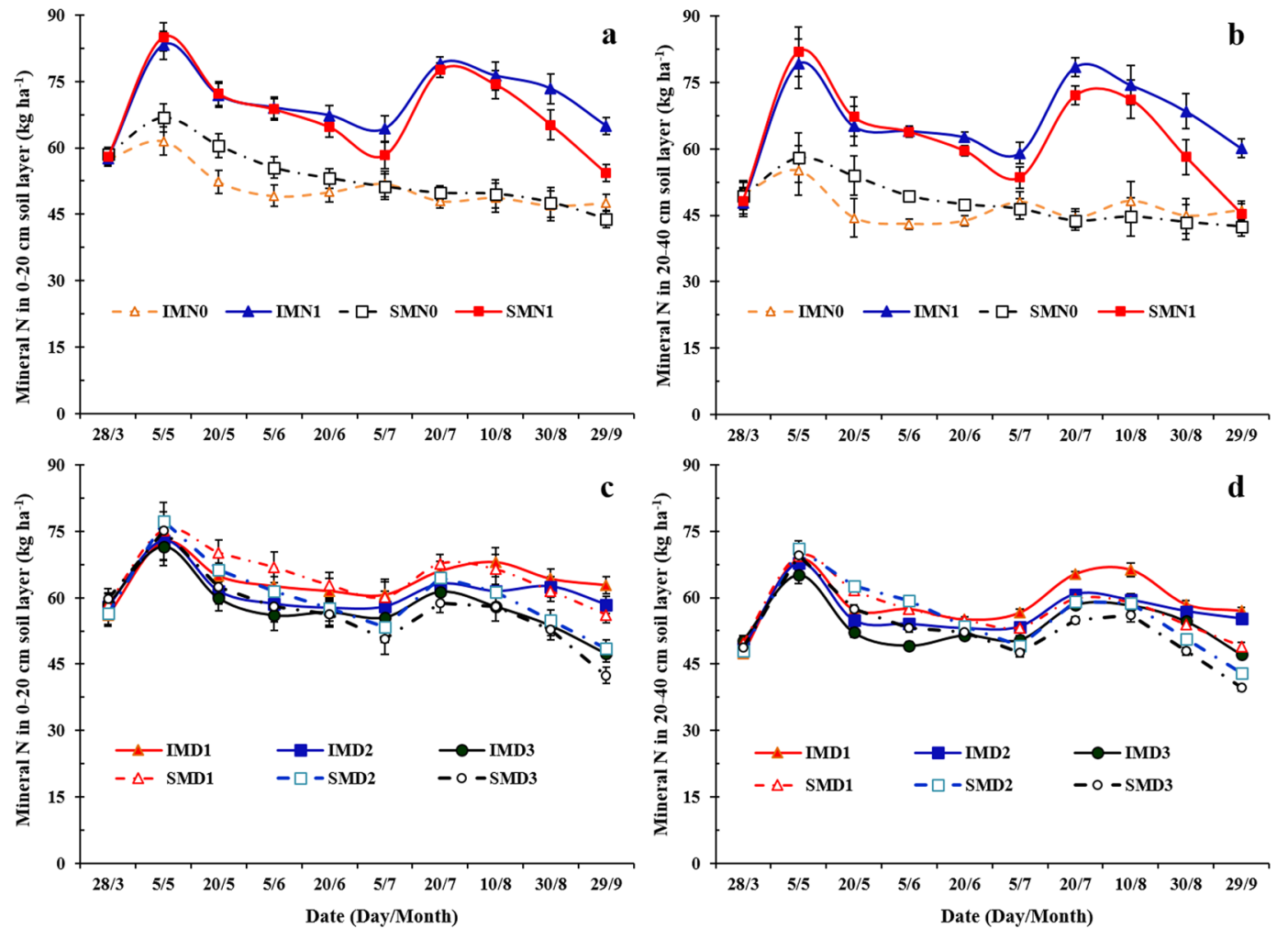

Figure 1. Mineral nitrogen (N) (ammonium-N + nitrate-N) in the $0-20 \mathrm{~cm}$ soil layer $(\mathbf{a}, \mathbf{c})$ and $20-40 \mathrm{~cm}$ soil layer (b,d) of intercropped maize (IM) or sole maize (SM) with two $\mathrm{N}$ treatments (N0, $0 \mathrm{~kg} \mathrm{~N} \mathrm{ha}^{-1}$; and N1, $225 \mathrm{~kg} \mathrm{~N} \mathrm{ha}^{-1}$ for pea and $450 \mathrm{~kg} \mathrm{~N} \mathrm{ha}^{-1}$ for maize) (a,c) and three maize densities (D1, 73,600 plants ha ${ }^{-1}$; D2, 85,900 plants ha ${ }^{-1}$; and D3, 98,200 plants ha ${ }^{-1}$ for sole maize; the relative density of intercropped maize (according to the proportion of occupied area in intercropping) was 45,000, 52,500, and 60,000 plants ha ${ }^{-1}$ for D1, D2, and D3, respectively) (b,d). Error bars indicate standard errors of the means $(n=4$ for $(\mathbf{a}, \mathbf{b}) ; n=6$ for $(\mathbf{c}, \mathbf{d}))$.

by $20-40 \%$ in maize (Zea mays L.), while perfect knowledge of potential crop $\mathrm{N}$ demands would reduce $\mathrm{N}$ rates by $3-10 \%$, and combined knowledge of both factors would reduce $\mathrm{N}$ rates significantly more than the sum of their individual effects ${ }^{16}$. Studies on improving $\mathrm{N}$ use efficiency (NUE) of cereal/legume intercropping systems have primarily focused on certain specific interspecific interactions, $\mathrm{N}$ fertilization rates, and $\mathrm{N}$ management ${ }^{17}$, irrespective of the relationship between soil N supply and crop N demand. Strategies should be taken to improve the synchrony of $\mathrm{N}$ supply and demand in farming systems, thereby increasing NUE.

Plant density can be used as a regulator for specific purposes, such as achieving high $\mathrm{N}$ yield ${ }^{18}$. Legumes under severe competition from maize show more efficient use of scarce resources, such as available soil $\mathrm{N}^{19-21}$. Additionally, greater plant density of the cereal may enhance its competition relative to the legume in intercropping systems ${ }^{22}$. The greater demand of cereal intercrops for soil inorganic $\mathrm{N}$ may force the legume to rely on $\mathrm{N}_{2}$ fixation, and enhance the balance between crop $\mathrm{N}$ demand and $\mathrm{N}$ supply. Understanding the response of soil mineral $\mathrm{N}$ and the balance between $\mathrm{N}$ supply and crop $\mathrm{N}$ demand as affected by plant density of the cereal is vital to maximizing grain yield and NUE of cereal/legume strip intercropping systems. We hypothesized that in a maize/pea (Pisum sativum L.) strip intercropping system, (i) the effect of maize plant density on soil mineral $\mathrm{N}$ could improve symbiotic $\mathrm{N}$ fixation of pea and increase $\mathrm{N}$ accumulation and yield of the intercrops, and (ii) the synchrony between crop $\mathrm{N}$ demand and $\mathrm{N}$ supply (via fertilizer applications or organic matter mineralization) with excessive $\mathrm{N}$ fertilizer inputs would be improved with maize at a greater plant density. Therefore, the following were measured: (i) soil mineral $\mathrm{N}$ variation in intercropping and sole cropping systems during the growing season, (ii) symbiotic $\mathrm{N}$ fixation of pea and $\mathrm{N}$ accumulation of component intercrops, (iii) the balance between $\mathrm{N}$ demand and supply in intercropping and sole cropping systems, and (iv) yield and $\mathrm{N}$ use efficiency of pea and maize in intercropping and sole cropping systems.

\section{Results}

Soil mineral N. Greater soil mineral N was observed in the intercropped maize strips than that of sole maize at certain growth stages (Fig. 1). In the $0-20 \mathrm{~cm}$ soil layer, mineral $\mathrm{N}$ of intercropped maize strips was greater than that of sole maize by an average of 10,13 , and $20 \%$ on July 5 (the pea harvest date), August 30, and September 29, respectively. In the $20-40 \mathrm{~cm}$ soil layer, mineral $\mathrm{N}$ of intercropped maize strips averaged $5-33 \%$ greater than that of sole maize from July 5 to September 29 (Fig. 1a,b). Compared to sole maize with $\mathrm{N}$ application, soil mineral $\mathrm{N}$ content in intercropped maize strips with $\mathrm{N}$ application was 33 and $36 \%$ greater in the $0-20 \mathrm{~cm}$ and $20-40 \mathrm{~cm}$ 

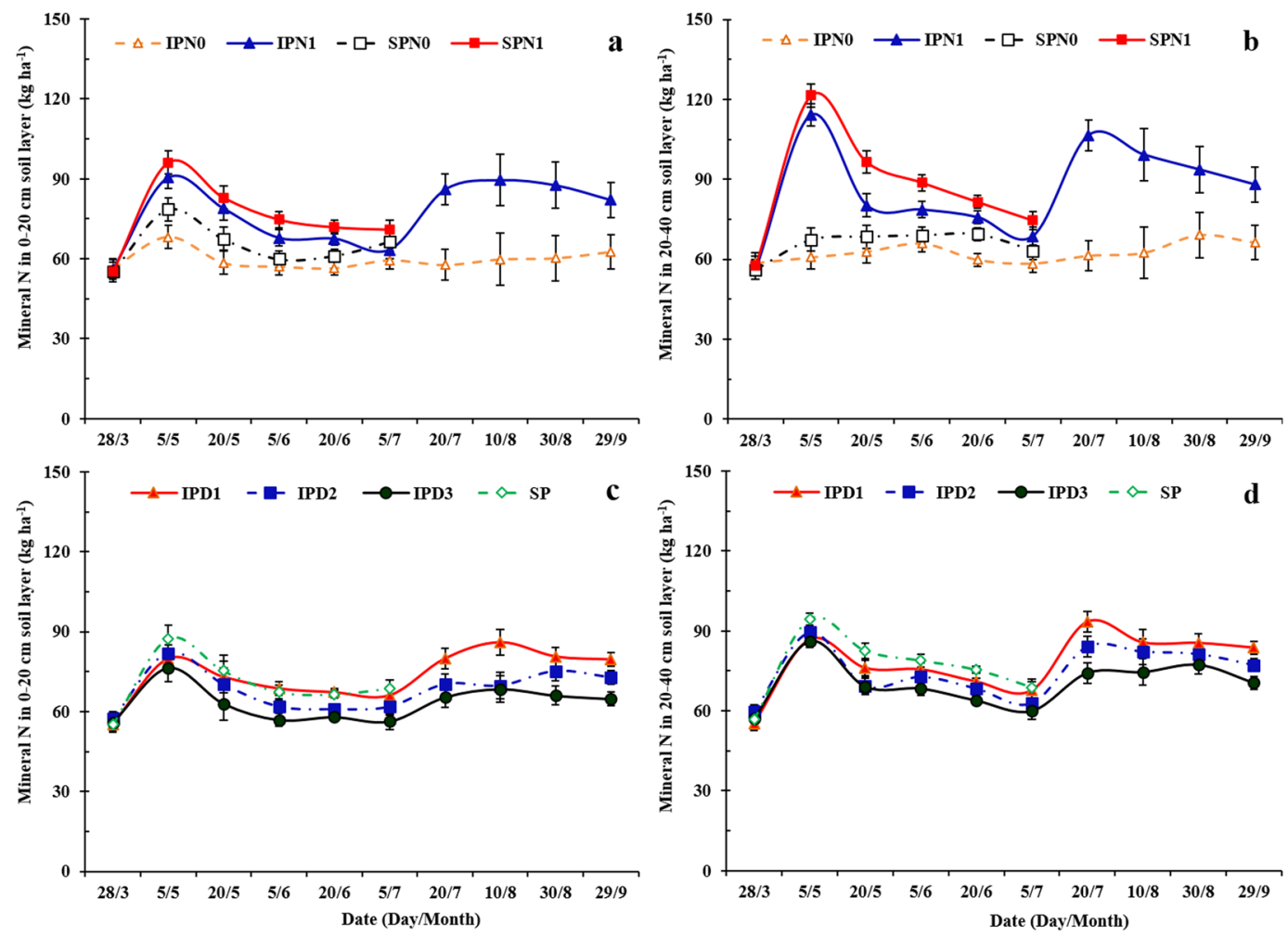

Figure 2. Mineral nitrogen $(\mathrm{N})($ ammonium-N + nitrate-N) in the $0-20 \mathrm{~cm}$ soil layer $(\mathbf{a}, \mathbf{c})$ and $20-40 \mathrm{~cm}$ soil layer (b,d) of intercropped pea (IP) or sole pea (SP) with two $\mathrm{N}$ treatments (N0, $0 \mathrm{~kg} \mathrm{~N} \mathrm{ha}^{-1}$; and N1, $225 \mathrm{~kg} \mathrm{~N}^{-}$ $\mathrm{ha}^{-1}$ for pea and $450 \mathrm{~kg} \mathrm{~N} \mathrm{ha}^{-1}$ for maize) (a,c) and three maize densities in intercropping (D1, 73,600 plants $\mathrm{ha}^{-1}$; D2, 85,900 plants ha ${ }^{-1}$; and D3, 98,200 plants ha ${ }^{-1}$ for sole maize; the relative density of intercropped maize (according to the proportion of occupied area in intercropping) was 45,000, 52,500, and 60,000 plants $\mathrm{ha}^{-1}$ for D1, D2, and D3, respectively) $(\mathbf{b}, \mathbf{d})$. Error bars indicate standard errors of the means $(n=4)$.

layers, respectively. Soil mineral $\mathrm{N}$ of sole and intercropped maize strips decreased with increasing maize plant density (Fig. 1c,d). Soil mineral N content in maize strips decreased by 6 and $5 \%$ in the $0-20$ and $20-40 \mathrm{~cm}$ soil layers, respectively, as maize plant density increased from D1 (45,000 plants ha $\left.{ }^{-1}\right)$ to D2 (52,500 plants ha $\left.{ }^{-1}\right)$; soil mineral $\mathrm{N}$ in maize strips decreased by 3.3 and $4.9 \%$ in the $0-20$ and $20-40 \mathrm{~cm}$ layers, respectively, as maize density increased from D2 to D3 (60,000 plants ha $\left.{ }^{-1}\right)$.

Soil mineral $\mathrm{N}$ content of pea strips changed substantially during the growing season (Fig. 2), with no significant year-by-treatment interactions observed. During the co-growth period (before pea harvest), intercropped pea strips had less soil mineral $\mathrm{N}$ compared to that of sole pea (Fig. 2a,b). From 5 May to 5 July, mineral $\mathrm{N}$ in the $0-20$ and $20-40 \mathrm{~cm}$ soil layers of intercropped pea was $6.8-10.6 \%$ and $7.7-12.6 \%$ less than that of sole pea, respectively. Soil mineral $\mathrm{N}$ of intercropped pea increased with the application of $\mathrm{N}$; this was most notable during the later part of the growing season of maize, as well as after pea harvest (from 20 July to 29 September). Mineral $\mathrm{N}$ content in intercropped pea strips with $\mathrm{N}$ application (IPN1) was 28.7 and $37.6 \%$ greater than that in the intercropped pea without $\mathrm{N}$ application (IPN0) for the $0-20 \mathrm{~cm}$ and $20-40 \mathrm{~cm}$ soil layers, respectively. Increasing maize plant density reduced the soil mineral $\mathrm{N}$ of intercropped pea strips during the growing period from 20 May to 29 September (Fig. 2c,d). Mineral N in the $0-20$ and $20-40 \mathrm{~cm}$ soil layers of the intercropped pea strips decreased by $3.9-18.9 \%$ and $3.6-9.9 \%$, respectively, when maize density increased from D1 to D2; it decreased by $4.9-12.3 \%$ and $4.5-11.8 \%$ in the $0-20$ and $20-40 \mathrm{~cm}$ soil layers, respectively, when maize density increased from D2 to D3.

Compared to sole maize, intercropped maize strips had $14 \%$ greater mineral $\mathrm{N}$ content in the $0-120 \mathrm{~cm}$ soil layers at maize harvest (Fig. 3a). The application of $\mathrm{N}$ significantly increased soil mineral $\mathrm{N}$ content in both intercropped and sole maize strips. Mineral N content in the $0-120 \mathrm{~cm}$ soil layer of maize strips with $\mathrm{N}$ application (N1) was $20 \%$ greater than that without N application (N0). Similar to pea, mineral N content in the $0-120 \mathrm{~cm}$ soil layer of intercropped and sole maize strips decreased by 9 and $12 \%$ as maize plant density increased from D1 to D2 and from D2 to D3, respectively. At pea harvest, total mineral N content in the $0-120 \mathrm{~cm}$ soil layer of pea strips differed significantly among treatments, with no significant year-by-treatment interactions (Fig. 3b). Intercropped pea strips had $13 \%$ less mineral $\mathrm{N}$ in the $0-120 \mathrm{~cm}$ soil layer than sole pea. Compared to N0, N1 significantly increased mineral $\mathrm{N}$ in the $0-120 \mathrm{~cm}$ soil layer of pea. Increasing maize plant density decreased soil mineral $\mathrm{N}$ content of intercropped pea strips. Soil mineral $\mathrm{N}$ content of intercropped pea strips was reduced by 7 and $10 \%$ as maize plant density increased from D1 to D2 and from D2 to D3, respectively. 

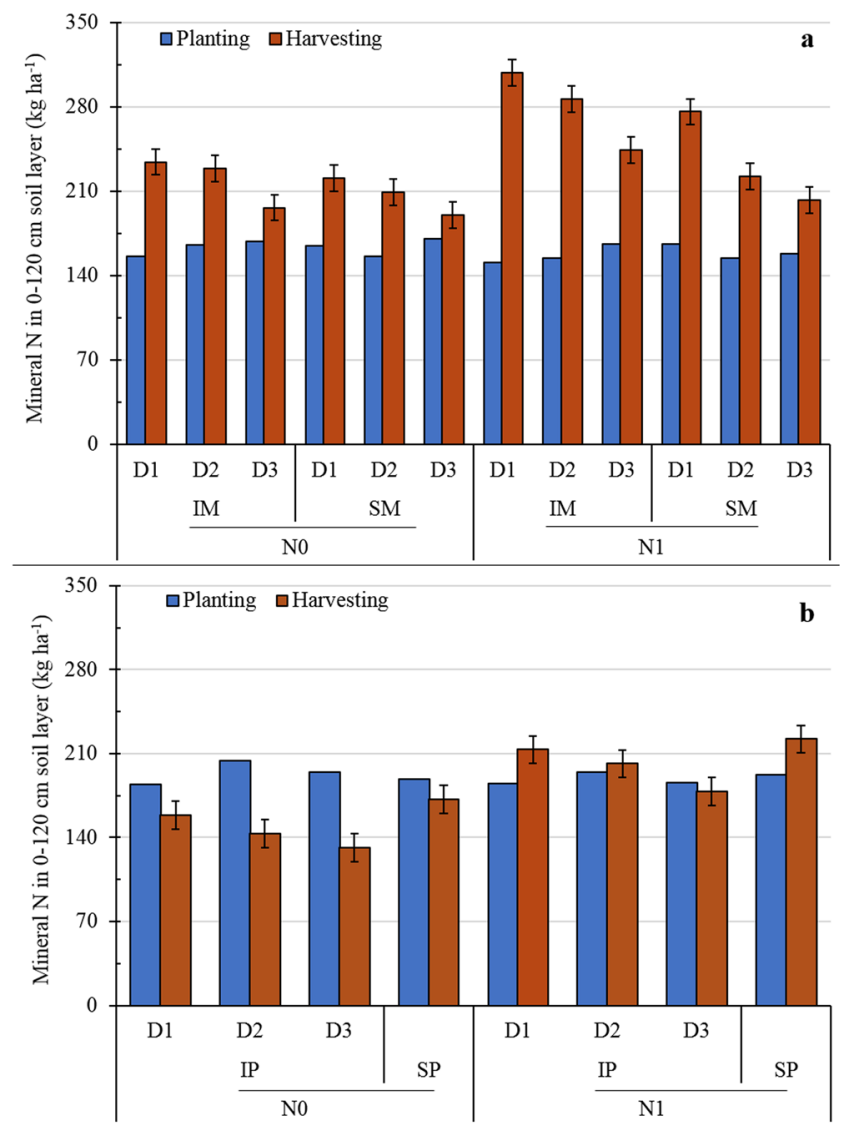

Figure 3. Mineral nitrogen (N) (ammonium-N + nitrate-N) in the $0-120 \mathrm{~cm}$ soil layer of intercropped pea (IP) or sole pea (SP) (a) and intercropped maize (IM) or sole maize (SM) (b) with two N treatments (N0, $0 \mathrm{~kg} \mathrm{~N}$ $\mathrm{ha}^{-1}$; and $\mathrm{N} 1,225 \mathrm{~kg} \mathrm{~N} \mathrm{ha}^{-1}$ for pea and $450 \mathrm{~kg} \mathrm{~N} \mathrm{ha}^{-1}$ for maize) (b) and three maize densities in intercropping (D1, 73,600 plants ha ${ }^{-1}$; D2, 85,900 plants ha ${ }^{-1}$; and D3, 98,200 plants ha ${ }^{-1}$ for sole maize; the relative density of intercropped maize (according to the proportion of occupied area in intercropping) was 45,000, 52,500, and 60,000 plants ha ${ }^{-1}$ for D1, D2, and D3, respectively) $(\mathbf{b}, \mathbf{d})$. Error bars indicate standard errors of the means $(n=4)$.

Crop $\mathrm{N}$ accumulation. Cropping system, $\mathrm{N}$ rate, and maize plant density significantly influenced total $\mathrm{N}$ accumulation in maize (Table 1). Total $\mathrm{N}$ accumulation of intercropped maize reached $76 \%$ of that of sole maize. Nitrogen application significantly increased total $\mathrm{N}$ accumulation of maize compared to N0. On average, total $\mathrm{N}$ accumulation of maize increased by 16 and $8 \%$ when maize plant density increased from D1 to D2 and from $\mathrm{D} 2$ to D3, respectively. The response of maize seed $\mathrm{N}$ to cropping system, $\mathrm{N}$ rate, and maize planting density was similar to that of total $\mathrm{N}$ accumulation. Seed $\mathrm{N}$ accounted for $66 \%$ of the total $\mathrm{N}$ accumulation by maize, which was increased by $7 \%$ when intercropped with pea.

Total $\mathrm{N}$ accumulation of intercropped pea reached $54 \%$ of that of sole pea (Table 1 ). Total $\mathrm{N}$ accumulation of intercropped pea with $\mathrm{N}$ application (N1) was $30 \%$ greater than that of pea with N0. Increasing maize plant density reduced total $\mathrm{N}$ accumulation of intercropped pea. The D3 intercropped pea exhibited $20 \%$ less total $\mathrm{N}$ accumulation than that of D1 and 16\% less than that of D2. The effect of cropping system, $\mathrm{N}$ rate, and maize plant density on pea seed $\mathrm{N}$ was similar to that of total $\mathrm{N}$ accumulation of pea. Seed $\mathrm{N}$ accounted for $60 \%$ of the total $\mathrm{N}$ accumulation by pea. Increasing maize plant density increased the ratio of seed $\mathrm{N}$ to total $\mathrm{N}$ accumulation of intercropped pea. Seed $\mathrm{N}$ represented 54, 60, and 66\% of total $\mathrm{N}$ accumulation of pea for D1, D2, and D3, respectively.

Total $\mathrm{N}$ accumulation of intercrops was significantly greater than that of the corresponding sole crops (Table 2). With $\mathrm{N}$ application, total aboveground $\mathrm{N}$ accumulation of maize/pea intercrops was $8-12 \%$ greater than that of sole maize and $34-53 \%$ greater than that of sole pea. The interaction between $\mathrm{N}$ treatment and maize plant density significantly influenced total $\mathrm{N}$ accumulation of intercrops. Without $\mathrm{N}$ application, total $\mathrm{N}$ accumulation of intercrops was not affected by maize plant density. With $\mathrm{N}$ application $\left(\mathrm{N} 1,225 \mathrm{~kg} \mathrm{~N} \mathrm{ha}^{-1}\right.$ for pea and $450 \mathrm{~kg} \mathrm{~N} \mathrm{ha}^{-1}$ for maize), total $\mathrm{N}$ accumulation of intercrops increased by 10 and $4 \%$ as maize plant density increased from D1 to D2 and from D2 to D3, respectively.

There was a marked advantage of intercropping for crop $\mathrm{N}$ accumulation, as the total $\mathrm{N}$ equivalent ratio (NER) for maize/pea intercrops ranged from 1.00 to 1.29 (Table 2). The NER of maize/pea intercrops with $\mathrm{N}$ application was $5-26 \%$ greater than that with N0. For the N1 treatment, the advantage of intercropping on crop N 


\begin{tabular}{|c|c|c|c|c|c|c|}
\hline \multirow[b]{2}{*}{ Effect } & \multicolumn{3}{|l|}{ Maize } & \multicolumn{3}{|l|}{ Pea } \\
\hline & Seed N & Straw N & $\begin{array}{l}\text { Total N } \\
\text { accumulation }\end{array}$ & Seed $\mathrm{N}$ & Straw N & $\begin{array}{l}\text { Total N } \\
\text { accumulation }\end{array}$ \\
\hline & \multicolumn{6}{|l|}{$\mathrm{kg} \mathrm{ha}^{-1}$} \\
\hline \multicolumn{7}{|l|}{ Year } \\
\hline 2012 & 150 & 43 & 193 & 87 & 64 & 151 \\
\hline 2013 & 107 & 96 & 202 & 84 & 45 & 129 \\
\hline 2014 & 135 & 75 & 210 & 79 & 62 & 142 \\
\hline $\mathrm{LSD}_{(0.05)}$ & 56 & 59 & 37 & 16 & 35 & 39 \\
\hline \multicolumn{7}{|l|}{ Cropping system } \\
\hline Intercropping & 118 & 57 & 175 & 70 & 46 & 116 \\
\hline Sole cropping & 143 & 86 & 229 & 124 & 89 & 214 \\
\hline $\mathrm{LSD}_{(0.05)}$ & 43 & 21 & 99 & 37 & 41 & 73 \\
\hline \multicolumn{7}{|l|}{ Nitrogen rate } \\
\hline $\mathrm{N}_{0}$ & 108 & 38 & 146 & 74 & 50 & 124 \\
\hline $\mathrm{N}_{1}$ & 153 & 105 & 257 & 93 & 64 & 157 \\
\hline $\operatorname{LSD}_{(0.05)}$ & 34 & 52 & 57 & 12 & 11 & 24 \\
\hline \multicolumn{7}{|l|}{ Maize density } \\
\hline $\mathrm{D}_{1}$ & 114 & 64 & 178 & 70 & 57 & 127 \\
\hline $\mathrm{D}_{2}$ & 132 & 74 & 206 & 73 & 48 & 121 \\
\hline $\mathrm{D}_{3}$ & 146 & 77 & 222 & 67 & 34 & 101 \\
\hline \multirow[t]{2}{*}{$\operatorname{LSD}_{(0.05)}$} & 16 & 7 & 18 & 5 & 10 & 15 \\
\hline & \multicolumn{6}{|l|}{$P>F$} \\
\hline Year $(\mathrm{Y})$ & $\mathrm{NS}^{\mathrm{a}}$ & NS & NS & NS & NS & NS \\
\hline Cropping system (C) & 0 & 0.019 & 0.002 & 0.001 & 0.004 & 0.007 \\
\hline Nitrogen rate $(\mathrm{N})$ & 0 & 0.001 & 0.013 & 0.011 & 0.001 & 0.001 \\
\hline Maize density (D) & 0.002 & 0.041 & 0.029 & 0.021 & 0.013 & 0.033 \\
\hline $\mathrm{C} \times \mathrm{N}$ & NS & NS & NS & NS & NS & NS \\
\hline $\mathrm{N} \times \mathrm{D}$ & NS & NS & NS & NS & NS & NS \\
\hline $\mathrm{D} \times \mathrm{C}$ & NS & NS & 0.039 & NS & NS & NS \\
\hline
\end{tabular}

Table 1. Seed N, straw $\mathrm{N}$ and total $\mathrm{N}$ accumulation of maize and pea planted in intercropping or sole cropping, with two $\mathrm{N}$ treatments (N0, $0 \mathrm{~kg} \mathrm{~N} \mathrm{ha}^{-1}$; and N1, $225 \mathrm{~kg} \mathrm{~N} \mathrm{ha}^{-1}$ for pea and $450 \mathrm{~kg} \mathrm{~N}^{-1}$ for maize) and three maize densities (D1, 73,600 plants ha ${ }^{-1}$; D2, 85,900 plants ha ${ }^{-1}$; and D3, 98,200 plants ha $^{-1}$ for sole maize; the relative density of intercropped maize (according to the proportion of occupied area in intercropping) was $45,000,52,500$, and 60,000 plants ha ${ }^{-1}$ for D1, D2, and D3, respectively) ${ }^{\mathrm{b}} .{ }^{\mathrm{a}} \mathrm{NS}$, not significant at the 0.05 probability level. ${ }^{b}$ Values are means $(n=3)$.

\begin{tabular}{|c|c|c|c|c|c|c|c|}
\hline \multirow[b]{2}{*}{ Nitrogen rates } & \multirow[b]{2}{*}{$\begin{array}{l}\text { Maize } \\
\text { density }\end{array}$} & \multicolumn{3}{|c|}{$\mathrm{N}$ accumulation $\left(\mathrm{kg} \mathrm{ha}^{-1}\right)$} & \multicolumn{3}{|c|}{$\mathrm{N}$ equivalent ratio (NER) } \\
\hline & & \begin{tabular}{|l|}
$\begin{array}{l}\text { Sole } \\
\text { pea }\end{array}$ \\
\end{tabular} & \begin{tabular}{|l}
$\begin{array}{l}\text { Sole } \\
\text { maize }\end{array}$ \\
\end{tabular} & Intercrops & Pea & Maize & Total \\
\hline \multirow{3}{*}{ No } & D1 & 198 & 161 & 205 & $0.55 \pm 0.02^{\mathrm{a}}$ & $0.60 \pm 0.05$ & $1.16 \pm 0.07$ \\
\hline & $\mathrm{D} 2$ & & 181 & 214 & $0.54 \pm 0.04$ & $0.61 \pm 0.06$ & $1.15 \pm 0.04$ \\
\hline & D3 & & 214 & 204 & $0.46 \pm 0.03$ & $0.54 \pm 0.02$ & $1.00 \pm 0.05$ \\
\hline \multirow{3}{*}{ N1 } & D1 & 230 & 281 & 308 & $0.61 \pm 0.02$ & $0.61 \pm 0.03$ & $1.22 \pm 0.03$ \\
\hline & D2 & & 313 & 339 & $0.59 \pm 0.02$ & $0.66 \pm 0.02$ & $1.26 \pm 0.02$ \\
\hline & D3 & & 314 & 353 & $0.56 \pm 0.05$ & $0.73 \pm 0.04$ & $1.29 \pm 0.03$ \\
\hline \multicolumn{2}{|l|}{$\operatorname{LSD}_{(0.05)}$} & \multicolumn{3}{|l|}{13.7} & & & \\
\hline & & & & $P>F$ & & & \\
\hline \multicolumn{2}{|l|}{ Nitrogen rate $(\mathrm{N})$} & & & 0.000 & 0.001 & 0.000 & 0.034 \\
\hline Maize density (D) & & & & 0.013 & 0.019 & 0.021 & 0.023 \\
\hline $\mathrm{L} \times \mathrm{D}$ & & & & 0.029 & $\mathrm{NS}^{\mathrm{b}}$ & 0.035 & 0.042 \\
\hline
\end{tabular}

Table 2. Nitrogen $(\mathrm{N})$ accumulation of intercrops relative to corresponding sole crops with two $\mathrm{N}$ treatments (N0, $0 \mathrm{~kg} \mathrm{~N} \mathrm{ha}^{-1}$; and $\mathrm{N} 1,225 \mathrm{~kg} \mathrm{~N} \mathrm{ha}^{-1}$ for pea and $450 \mathrm{~kg} \mathrm{~N} \mathrm{ha}^{-1}$ for maize) and three maize densities (D1, 73,600 plants ha ${ }^{-1}$; D2, 85,900 plants ha ${ }^{-1}$; and D3, 98,200 plants ha ${ }^{-1}$ for sole maize; the relative density of intercropped maize (according to the proportion of occupied area in intercropping) was 45,000, 52,500,

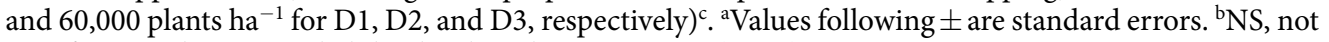
significant at the 0.05 probability level. ${ }^{c}$ Values are means $(n=6)$. 

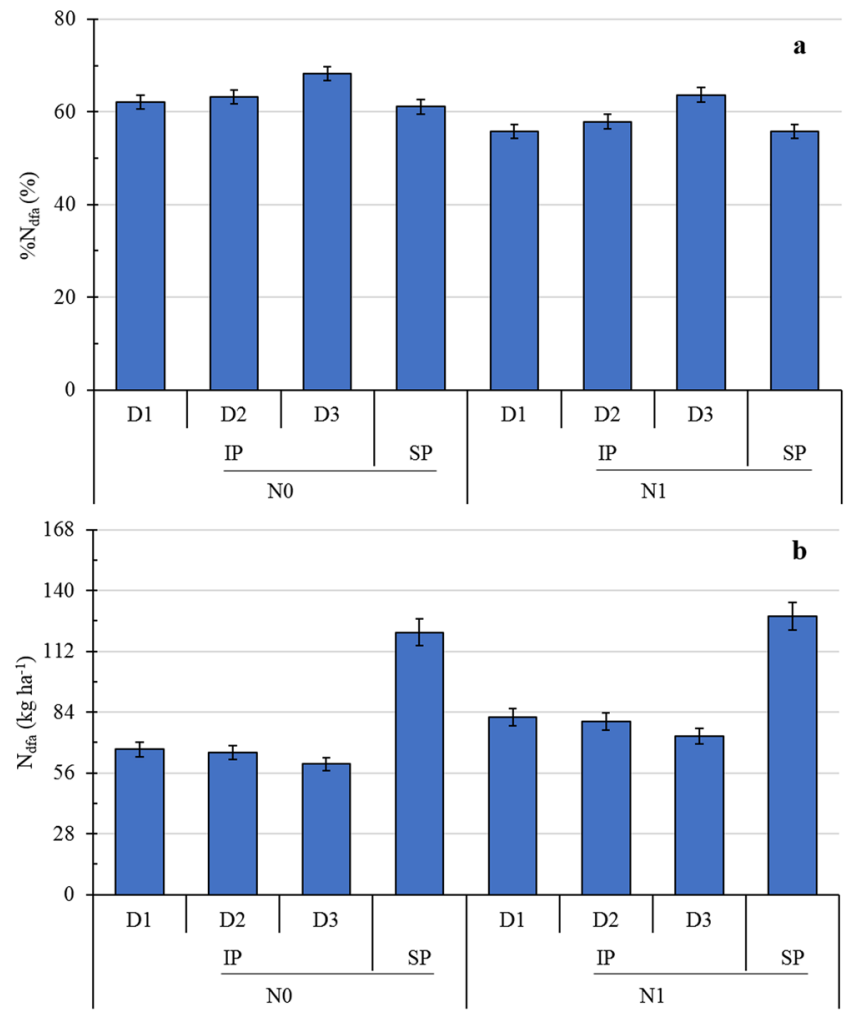

Figure 4. The percentage of total aboveground $\mathrm{N}$ accumulation derived from $\mathrm{N}_{2}$ fixation $\left(\% \mathrm{~N}_{\mathrm{dfa}}\right)($ a) and the calculation $\mathrm{N}$ derived from the atmosphere $\left(\mathrm{N}_{\mathrm{dfa}}\right)(\mathbf{b})$ of intercropped pea (IP) or sole pea (SP), with two $\mathrm{N}$ treatments (N0, $0 \mathrm{~kg} \mathrm{~N} \mathrm{ha}^{-1}$; and $\mathrm{N} 1,225 \mathrm{~kg} \mathrm{~N} \mathrm{ha}^{-1}$ for pea and $450 \mathrm{~kg} \mathrm{~N} \mathrm{ha}^{-1}$ for maize) and three maize densities (D1, 73,600 plants ha ${ }^{-1}$; D2, 85,900 plants ha ${ }^{-1}$; and D3, 98,200 plants ha ${ }^{-1}$ for sole maize; the relative density of intercropped maize (according to the proportion of occupied area in intercropping) was 45,000, 52,500 , and 60,000 plants ha ${ }^{-1}$ for D1, D2, and D3, respectively).

accumulation was enhanced with increased maize plant density; the NER increased by 3 and $2 \%$ as maize planting density increased from D1 to D2 and from D2 to D3, respectively. The advantage of intercropping on maize $\mathrm{N}$ accumulation was influenced by the interaction between $\mathrm{N}$ treatment and maize plant density. With $\mathrm{N} 0$, the partial NER for maize in the D3 treatment was 10 and 11\% less than that of maize in the D1 and D2 treatments, respectively. For N1, partial NER for maize increased by 8 and $10 \%$ as maize plant density increased from D1 to $\mathrm{D} 2$ and from $\mathrm{D} 2$ to $\mathrm{D} 3$, respectively. The advantage of intercropping for $\mathrm{N}$ accumulation of pea was diminished in D3 compared with D1 and D2. The partial NER for pea in the D3 treatment was 12 and $10 \%$ less than that of pea in the D1 and D2 treatments, respectively.

$\mathbf{N}$ fixation and $\% \mathbf{N}_{\mathrm{dfa}}$ of pea. The percentage of total aboveground $\mathrm{N}$ accumulation for pea, derived from $\mathrm{N}_{2}$-fixation $\left(\% \mathrm{~N}_{\mathrm{dfa}}\right)$ did not differ between intercropped pea and sole pea (Fig. $\left.4 \mathrm{a}\right)$. The $\% \mathrm{~N}_{\mathrm{dfa}}$ of intercropped and sole pea was $9 \%$ less with $\mathrm{N} 1$ compared to N0. The $\% \mathrm{~N}_{\mathrm{dfa}}$ of intercropped pea increased with increasing maize planting density. The $\% \mathrm{~N}_{\mathrm{dfa}}$ of intercropped pea in treatment D3 was 2 and $9 \%$ greater than that of pea in D1 and D2, respectively.

Nitrogen derived from the atmosphere $\left(\mathrm{N}_{\mathrm{dfa}}\right)$ of intercropped pea reached $57 \%$ of that of sole pea (Fig. $\left.4 \mathrm{~b}\right)$. The $\mathrm{N}_{\mathrm{dfa}}$ of pea was significantly enhanced by $\mathrm{N}$ application. The $\mathrm{N}_{\mathrm{dfa}}$ of pea with $225 \mathrm{kgha}^{-1} \mathrm{~N}$ application (N1) was $18 \%$ greater than that in treatment N0. The $\mathrm{N}_{\mathrm{dfa}}$ of intercropped pea in treatment $\mathrm{D} 3$ was 11 and $8 \%$ less than that of pea in D1 and D2, respectively.

Balance between crop $\mathbf{N}$ demand and $\mathbf{N}$ supply. Cropping system, $\mathrm{N}$ treatment, and maize plant density significantly influenced the balance between crop $\mathrm{N}$ demand and $\mathrm{N}$ supply $(\Delta \mathrm{N})$ during the growing season (Fig. 5). The value of $\Delta \mathrm{N}$ of sole maize with applied $\mathrm{N}$ was negative (Fig. $5 \mathrm{a}$ ). With applied $\mathrm{N}$, intercropped maize exhibited a strongly enhanced $\mathrm{N}$ demand compared to that of sole maize. The difference between $\Delta \mathrm{N}$ of sole maize in D2 and D3 was not significant. However, the $\Delta \mathrm{N}$ of intercropped maize was increased by 39 and $16 \%$ as maize plant density increased from D1 to D2 and from D2 to D3, respectively. The N1 treatment restrained $\Delta \mathrm{N}$ in pea and maize strips compared to the N0 treatment. With applied $\mathrm{N}$, the average $\Delta \mathrm{N}$ for intercropped pea decreased by $34 \%$ compared to sole pea (Fig. $5 \mathrm{~b}$ ). The $\Delta \mathrm{N}$ of intercropped pea decreased by 21 and $24 \%$ as maize plant density increased from D1 to D2 and from D2 to D3, respectively. 

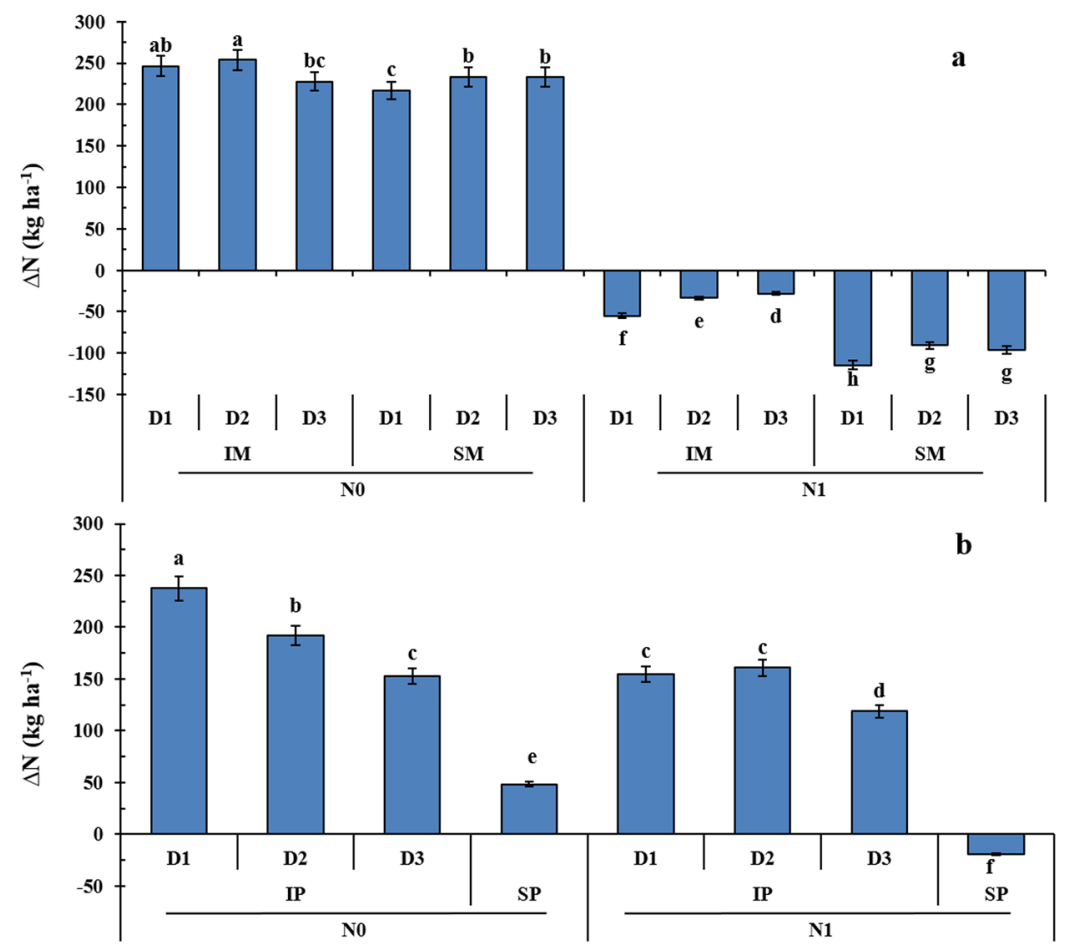

Figure 5. Balance between crop $\mathrm{N}$ demand and $\mathrm{N}$ supply $(\Delta \mathrm{N})$ during the growing period of intercropped pea (IP) or sole pea (SP) (a) and intercropped maize (IM) or sole maize (SM) (b) with two N treatments (N0, $0 \mathrm{~kg} \mathrm{~N} \mathrm{ha}^{-1}$; and N1, $225 \mathrm{~kg} \mathrm{~N} \mathrm{ha}^{-1}$ for pea and $450 \mathrm{~kg} \mathrm{~N} \mathrm{ha}^{-1}$ for maize) and three maize three maize densities (D1, 73,600 plants ha ${ }^{-1}$; D2, 85,900 plants ha ${ }^{-1}$; and D3, 98,200 plants ha ${ }^{-1}$ for sole maize; the relative density of intercropped maize (according to the proportion of occupied area in intercropping) was 45,000, 52,500, and 60,000 plants ha ${ }^{-1}$ for D1, D2, and D3, respectively). Error bars indicate standard errors of the means $(n=8$ for (a), $n=12$ for (b)). Dissimilar letters on bars means that are significantly different according to Fisher's protected LSD $(P \leq 0.05)$.

\begin{tabular}{|c|c|c|c|c|c|c|c|}
\hline \multirow{2}{*}{$\begin{array}{l}\text { Nitrogen } \\
\text { rates }\end{array}$} & \multirow{2}{*}{$\begin{array}{l}\text { Maize } \\
\text { density }\end{array}$} & \multicolumn{2}{|c|}{ Sole cropping } & \multicolumn{3}{|c|}{ Intercropping } & \multirow[b]{2}{*}{ LER $_{\text {grain }}^{\mathbf{a}}$} \\
\hline & & Pea & Maize & Pea & Maize & Total & \\
\hline & & \multicolumn{5}{|c|}{$\mathrm{kg} \mathrm{ha}^{-1}$} & \\
\hline \multirow{3}{*}{ No } & D1 & 3275 & 9459 & 1827 & 6511 & 8338 & $1.25 \pm 0.03^{b}$ \\
\hline & D2 & - & 10273 & 1783 & 9025 & 10808 & $1.26 \pm 0.04$ \\
\hline & D3 & - & 11577 & 1713 & 9231 & 10944 & $1.32 \pm 0.03$ \\
\hline \multirow{3}{*}{$\mathrm{N} 1$} & D1 & 4679 & 10499 & 2188 & 8086 & 10274 & $1.24 \pm 0.02$ \\
\hline & D2 & - & 12228 & 2083 & 9638 & 11855 & $1.24 \pm 0.03$ \\
\hline & D3 & - & 12219 & 1890 & 10916 & 12806 & $1.30 \pm 0.02$ \\
\hline \multicolumn{2}{|l|}{$\operatorname{LSD}_{(0.05)}$} & 652 & 989 & 185 & 386 & 862 & \\
\hline & & \multicolumn{6}{|l|}{$P>F$} \\
\hline Year $(\mathrm{Y})$ & & $\mathrm{NS}^{\mathrm{c}}$ & NS & NS & NS & NS & NS \\
\hline \multicolumn{2}{|c|}{ Nitrogen rate $(\mathrm{N})$} & 0.001 & 0.043 & 0.021 & 0.001 & 0.003 & NS \\
\hline \multicolumn{2}{|c|}{ Maize density (D) } & - & 0.029 & 0.002 & 0.041 & 0.029 & 0.047 \\
\hline $\mathrm{N} \times \mathrm{D}$ & & - & NS & NS & 0.038 & 0.042 & NS \\
\hline
\end{tabular}

Table 3. Performance of grain yield of intercropped pea and maize relative to corresponding sole crops with two $\mathrm{N}$ treatments (N0, $0 \mathrm{~kg} \mathrm{~N} \mathrm{ha}^{-1}$; and N1, $225 \mathrm{~kg} \mathrm{~N} \mathrm{ha}^{-1}$ for pea and $450 \mathrm{~kg} \mathrm{~N} \mathrm{ha}^{-1}$ for maize) and three maize densities (D1, 73,600 plants ha ${ }^{-1}$; D2, 85,900 plants ha ${ }^{-1}$; and D3, 98,200 plants ha ${ }^{-1}$ for sole maize; the relative density of intercropped maize (according to the proportion of occupied area in intercropping) was $45,000,52,500$, and 60,000 plants $\mathrm{ha}^{-1}$ for D1, D2, and D3, respectively) ${ }^{\mathrm{d}}$. ${ }^{\mathrm{L}} \mathrm{LER}$, land equivalent ratio. ${ }^{\mathrm{b}}$ Values following \pm are standard errors. ${ }^{c} \mathrm{NS}$, not significant at the 0.05 probability level. ${ }^{\mathrm{d}}$ Values are means $(n=3)$.

Grain yield, biomass, and NUE of intercrops. According to the land equivalent ratio (LER) of grain and biomass, intercropping increased total grain yield by $24-30 \%$ (Table 3 ) and biomass of maize and pea by $11-23 \%$ compared to sole cropping (Table 4). The LER for grain yield (LER grain $)$ of maize and pea intercropped with D3 


\begin{tabular}{|c|c|c|c|c|c|c|c|}
\hline \multirow{2}{*}{$\begin{array}{l}\text { Nitrogen } \\
\text { rates }\end{array}$} & \multirow{2}{*}{$\begin{array}{l}\text { Maize } \\
\text { density }\end{array}$} & \multicolumn{2}{|c|}{ Sole cropping } & \multicolumn{3}{|c|}{ Intercropping } & \multirow[b]{2}{*}{ LER $_{\text {biomass }}{ }^{a}$} \\
\hline & & Pea & Maize & Pea & Maize & Total & \\
\hline & & \multicolumn{5}{|l|}{$\mathrm{kg} \mathrm{ha}^{-1}$} & \\
\hline \multirow{3}{*}{ No } & D1 & 8798 & 16970 & 4130 & 10854 & 14984 & $1.11 \pm 0.04^{\mathrm{b}}$ \\
\hline & D2 & - & 19236 & 3990 & 14109 & 18099 & $1.13 \pm 0.02$ \\
\hline & D3 & - & 20183 & 3588 & 15457 & 19045 & $1.18 \pm 0.02$ \\
\hline \multirow{3}{*}{ N1 } & D1 & 10069 & 21061 & 4860 & 14707 & 19568 & $1.18 \pm 0.01$ \\
\hline & D2 & - & 23991 & 4738 & 17153 & 21891 & $1.19 \pm 0.01$ \\
\hline & D3 & - & 23652 & 4067 & 19435 & 23503 & $1.23 \pm 0.02$ \\
\hline \multicolumn{2}{|l|}{$\operatorname{LSD}_{(0.05)}$} & 849 & 1147 & 376 & 1370 & 1056 & \\
\hline & & \multicolumn{6}{|l|}{$P>F$} \\
\hline Year $(\mathrm{Y})$ & & $\mathrm{NS}^{\mathrm{c}}$ & NS & NS & NS & NS & NS \\
\hline \multicolumn{2}{|c|}{ Nitrogen rate $(\mathrm{N})$} & 0.001 & 0.003 & 0.001 & 0.013 & 0.002 & NS \\
\hline \multicolumn{2}{|c|}{ Maize density (D) } & - & 0.027 & 0.002 & 0.014 & 0.029 & 0.049 \\
\hline $\mathrm{N} \times \mathrm{D}$ & & - & NS & NS & NS & NS & NS \\
\hline
\end{tabular}

Table 4. Performance of biomass of intercropped pea and maize relative to corresponding sole crops with two $\mathrm{N}$ treatments (N0, $0 \mathrm{~kg} \mathrm{~N} \mathrm{ha}^{-1}$; and N1, $225 \mathrm{~kg} \mathrm{~N} \mathrm{ha}^{-1}$ for pea and $450 \mathrm{~kg} \mathrm{~N} \mathrm{ha}^{-1}$ for maize) and three maize densities (D1, 73,600 plants ha ${ }^{-1}$; D2, 85,900 plants ha ${ }^{-1}$; and D3, 98,200 plants ha ${ }^{-1}$ for sole maize; the relative density of intercropped maize (according to the proportion of occupied area in intercropping) was $45,000,52,500$, and 60,000 plants ha ${ }^{-1}$ for D1, D2, and D3, respectively) $)^{\mathrm{d}}$. $\mathrm{LER}$, land equivalent ratio. ${ }^{\mathrm{b}}$ Values following \pm are standard errors. ${ }^{c} \mathrm{NS}$, not significant at the 0.05 probability level. ${ }^{\mathrm{d}}$ Values are means $(n=3)$.

was 4.8 and $5.2 \%$ greater, respectively than that with $\mathrm{D} 1$ and $\mathrm{D} 2$. Additionally, the LER for biomass $\left(\mathrm{LER}_{\mathrm{biomass}}\right)$ of maize and pea intercropped with D3 was 3.9 and 5.3\% greater, respectively, than that with D1 and D2.

Significant grain yield (Table 3) and biomass (Table 4) differences were observed between intercropped and sole maize. The proportion of occupied area in intercropping by maize was $58 \%$. Averaged over years, $\mathrm{N}$ treatments, and plant density treatments, maize grain yield and biomass were 80 and $72 \%$ of that of sole maize, respectively. Maize grain yield and biomass increased by 14 and 25\%, respectively, with N1 compared to N0. Grain yield and biomass of sole maize with D2 were greater than that with D1, but they were not increased as plant density increased from D2 to D3. However, with the N1 treatment, grain yield and biomass of maize increased as plant density increased. Grain yield and biomass of intercropped maize increased by 19 and 17\%, respectively, as maize density increased from D1 to D2, and by 13 and 14\%, respectively, as the maize density increased from D2 to D3. The proportion of occupied area in intercropping by pea was $42 \%$. Grain yield and biomass of intercropped pea were 49 and $45 \%$ of that of sole pea, respectively. Pea grain yield and biomass increased by 22 and $16 \%$ with N1 compared to N0. In contrast with maize, grain yield and biomass of pea decreased as maize plant density increased. With the N1 treatment, grain yield of intercropped pea decreased by 5 and $9 \%$ as maize density increased from D1 to D3 and from D2 to D3, respectively. Similarly, biomass of intercropped pea was reduced by 3 and $14 \%$ as maize plant density increased from D1 to D2 and from D2 to D3, respectively. With the N1 treatment, total grain yield and biomass of maize/pea intercropping were greater with increased maize plant density.

Maize/pea intercropping resulted in greater NUE than the corresponding sole cropping systems (Fig. 6). With the D2 treatment, NUE of maize/pea intercrops was 4-40\% greater than that of sole maize and $124-184 \%$ greater than that of sole pea. With the D3 treatment, NUE of maize/pea intercrops was $26-113 \%$ greater than that of sole maize and $162-213 \%$ greater than that of sole pea. The NUE of maize/pea intercrops increased as maize plant density increased. The NUE of intercrops increased by 53\% in 2012 and $29 \%$ in 2014 as maize density increased from D1 to D2, and by 5\% in 2012, 11\% in 2013, and 40\% in 2014 as maize density increased from D2 to D3.

\section{Discussion}

The intensity of crop competition for soil $\mathrm{N}$ was significantly affected by soil $\mathrm{N}$ supply and plant density ${ }^{23}$. In this study, maize/pea intercropping resulted in interspecific complementary use of soil mineral $\mathrm{N}$ by crops. Maize intercropped with pea had greater soil mineral $\mathrm{N}$ than sole maize during maize growth after pea harvest. Additionally, less soil mineral $\mathrm{N}$ in intercropped pea compared to sole pea during the co-growth period forced pea to rely on $\mathrm{N}_{2}$ fixation. In intercropping systems, nutrient uptake of the dominant or early crop is increased during the co-growth stage because of interspecific interaction; however, after the dominant species or early crop is harvested, the subordinate or later crop undergoes a recovery or complementary process so that the final yield is equivalent or greater compared to corresponding solely planted species ${ }^{24}$. Intercropping with increased cereal density increased the competition indices ${ }^{25}$. This might be because cereal species with deep roots have strong $\mathrm{N}$ acquisition ability and are able to extend their roots into the neighboring legume strips to acquire more $\mathrm{N}^{26}$. In the present study, decreased soil mineral $\mathrm{N}$ in both intercropped pea and maize strips with increasing maize density indicates that increasing maize density enhanced the interspecific interaction for improving $\mathrm{N}$ uptake by intercrops.

Intercropping alters the $\mathrm{N}$ uptake rates of maize and legumes ${ }^{27}$. In the present study, maize/pea intercropping exhibited a greater advantage for total $\mathrm{N}$ accumulation in crops compared with the corresponding sole cropping systems. The total NER for maize/pea intercrops ranged from 1.15 to 1.29 , except for the treatment combination of N0 and D3. These results indicate that maize and pea had greater N complementation than competition in this 

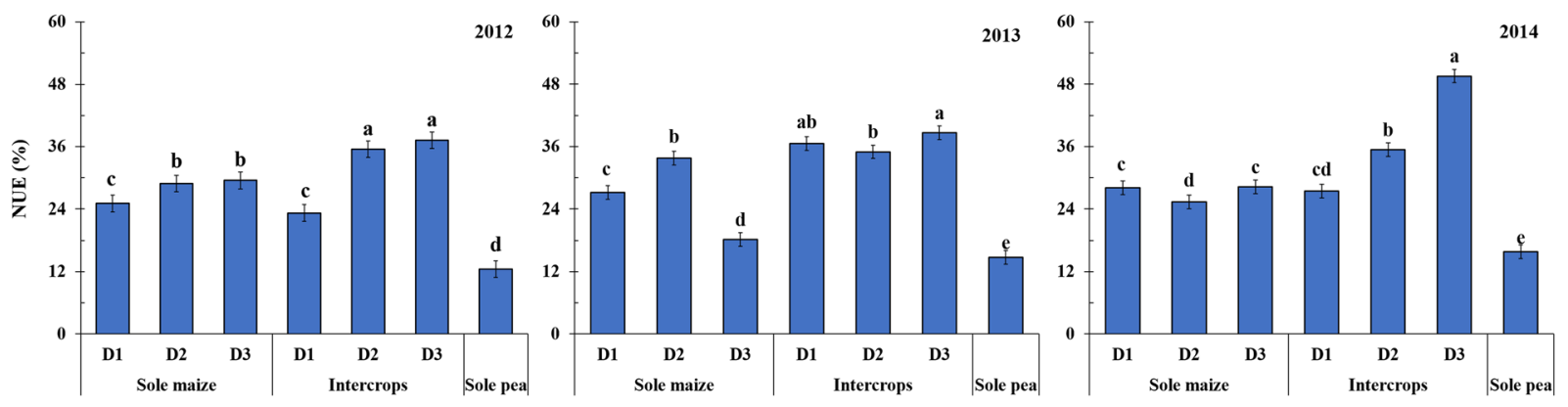

Figure 6. Apparent nitrogen use efficiency (NUE) of intercrops (maize and pea), sole maize, and sole pea from 2012 to 2014 with two $\mathrm{N}$ treatments (N0, $0 \mathrm{~kg} \mathrm{~N} \mathrm{ha}^{-1}$; and N1, $225 \mathrm{~kg} \mathrm{~N} \mathrm{ha}^{-1}$ for pea and $450 \mathrm{~kg} \mathrm{~N} \mathrm{ha}^{-1}$ for maize) and three maize three maize densities (D1, 73,600 plants ha ${ }^{-1} ; \mathrm{D} 2,85,900$ plants ha $^{-1}$; and D3, 98,200 plants ha ${ }^{-1}$ for sole maize; the relative density of intercropped maize (according to the proportion of occupied area in intercropping) was 45,000, 52,500, and 60,000 plants ha ${ }^{-1}$ for D1, D2, and D3, respectively). Error bars indicate standard errors of the means $(n=7)$. Dissimilar letters on bars means that are significantly different according to Fisher's protected LSD $(P \leq 0.05)$.

intercropping system. Moreover, the variation in partial NER for maize and pea with increasing maize plant density indicates that the competition of maize for $\mathrm{N}$ relative to that of pea was promoted by increasing maize density. With increasing maize density, the slight reduction in $\mathrm{N}$ accumulation of intercropped pea was compensated by the considerable increase in $\mathrm{N}$ accumulation of maize.

The $\% \mathrm{~N}_{\mathrm{dfa}}$ of legumes has been shown to increase with greater competition intensity between legume and cereal intercrops, which may be because $\mathrm{N}$ concentration in the legume rhizosphere is reduced by the nonleg$u_{m} e^{28}$. Conversely, in the present study, a significant difference in the $\% \mathrm{~N}_{\mathrm{dfa}}$ between intercropped and sole pea was not observed. The $\% \mathrm{~N}_{\mathrm{dfa}}$ of pea was significantly decreased with $\mathrm{N} 1$ compared to $\mathrm{N} 0$, which might be because symbiotic $\mathrm{N}_{2}$ fixation is typically inhibited by $\mathrm{N}$ fertilization since it increases soil mineral $\mathrm{N}^{29}$. Intercropped pea exhibited an increasing trend in $\% \mathrm{~N}_{\mathrm{dfa}}$ and a decreasing trend in $\mathrm{N}_{\mathrm{dfa}}$ with increased maize density. This is because biomass, rather than $\% \mathrm{~N}_{\mathrm{dfa}}$, was more critical for the legume to increase $\mathrm{N}_{\mathrm{dfa}}{ }^{30}$. The amount of symbiotically fixed $\mathrm{N}_{2}$ by pea was significantly correlated with its biomass.

When $\mathrm{N}$ supply (including fertilizer applications and organic matter mineralization) exceeds crop $\mathrm{N}$ demand, the excess soil $\mathrm{N}$ is susceptible to loss the environment ${ }^{6}$. Improving the balance between crop $\mathrm{N}$ demand and supply, a quantitative synchrony, is key to increasing NUE and sustainability in agroecosystems ${ }^{31,32}$. Intercropping with high maize density increased crop $\mathrm{N}$ demand, reducing soil mineral $\mathrm{N}$ and potential losses of soil $\mathrm{N}$ from excessive $\mathrm{N}$ fertilization. A high density of cereals enhances the intensity of competition for soil $\mathrm{N}$, which promotes $\mathrm{N}$ uptake by crops and reduces mineral $\mathrm{N}$ remaining in the soil ${ }^{33,34}$. In the present study, the values of $\Delta \mathrm{N}$ in pea strips were positive, while those in sole maize with $\mathrm{N}$ application were negative. Nitrogen fertilization decreased the $\Delta \mathrm{N}$ of pea and maize in intercropping or sole cropping systems. In sole maize with $\mathrm{N}$ application, $\mathrm{N}$ demand (total $\mathrm{N}$ accumulation) was substantially lower than $\mathrm{N}$ supply (residual soil $\mathrm{N}$ available at planting plus $\mathrm{N}$ supplied through fertilizer, minus residual soil $\mathrm{N}$ at crop harvest). Some of this excess $\mathrm{N}$ may be lost due to leaching, denitrification, or ammonia volatilization. When maize or pea were grown without $\mathrm{N}$ fertilization, their $\mathrm{N}$ demands were largely greater than $\mathrm{N}$ supply. Overall, intercropping can significantly improve the balance between crop $\mathrm{N}$ demand and $\mathrm{N}$ supply compared to sole cropping. Increasing the density of maize is a useful way to improve the balance between $\mathrm{N}$ supply and crop demand in maize/pea intercropping with $\mathrm{N}$ fertilization.

Intercropping typically increases land productivity and resource use efficiency ${ }^{35-37}$. In the present study, an advantage of intercropping in land productivity and $\mathrm{N}$ use according to LER and NER was observed compared to sole cropping. Moreover, the D3 treatment produced greater $\mathrm{LER}_{\text {grain }}$ and NUE than did D1 and D2. Intercropping reduced the growth of symbiotic legumes via the overshadowing effects of the cereal partner ${ }^{38}$. The plant density in intercropping was a proportion of the density in sole cropping (relative density was 0.58 for maize and 0.42 for pea). Grain yield of intercropped pea was $49 \%$ of sole pea, which was greater the proportion of pea occupied area and relative density (42\%) in intercropping. This indicates that grain yield of pea was improved by intercropping in pure occupied area compared to sole pea. This may be due to the earlier seedling emergence of pea compared to maize (approximately $15 \mathrm{~d}$ ). A recent study found that $\mathrm{N}$ addition did not increase total grain yield of pea/ barley (Hordeum vulgare L.) intercropping and decreased the contribution of pea $^{33}$. Other studies have found that grain yield of soybean [Glycine max (L.) Merr] in maize/soybean intercropping was increased by $24 \%$ with $\mathrm{N}$ application compared to that without $\mathrm{N}$ application ${ }^{39}$. In the present study, grain yield and biomass of maize and pea were greater with $\mathrm{N}$ application compared to without $\mathrm{N}$ application. Hybrid characteristics, along with soil and climate conditions, are important factor determining optimal maize plant density ${ }^{40}$. In intercropping, harsh environmental conditions may be ameliorated and the availability of resources may be increased for intercrops ${ }^{41}$. Furthermore, intercropping increases yield of its component crops as it uses soil nutrients more efficiently than sole cropping ${ }^{42}$. Therefore, higher plant density may be adopted with intercropping compared to sole cropping. A previous study on intercropping found that increasing maize plant density reduced legume grain yield and did not increase maize grain yield ${ }^{43}$. In the present study, D3 reduced intercropped pea grain yield compared with $\mathrm{D} 1$ and D2, consistent with the trend in biomass, but the increased grain yield of maize with increasing density 


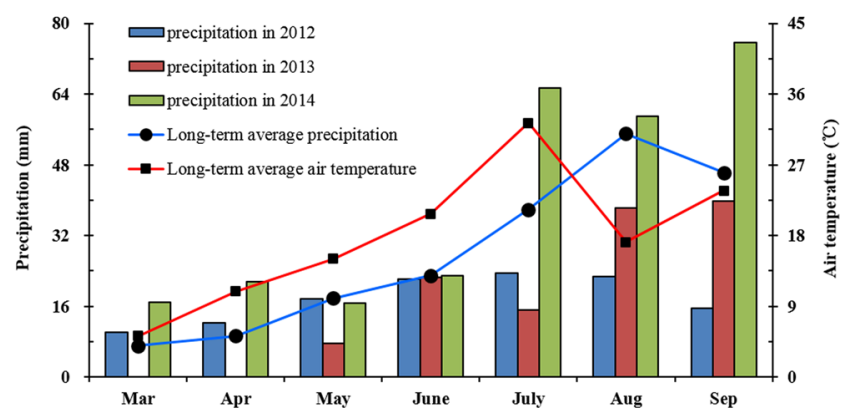

Figure 7. Monthly precipitation during the growing season (1 March to 30 September) in 2012, 2013, and 2014, and long-term average (2005-2014) monthly precipitation and average air temperature at the Oasis Experimental Station located in Wuwei, Gansu province of northwestern China.

\begin{tabular}{|c|c|c|c|c|c|c|c|c|c|}
\hline \multirow[b]{2}{*}{ Year } & \multirow{2}{*}{$\begin{array}{l}\text { Layer } \\
(\mathrm{cm})\end{array}$} & \multirow{2}{*}{$\begin{array}{l}\text { Bulk } \\
\text { density } \\
\left(\mathrm{g} \mathrm{cm}^{-3}\right)\end{array}$} & $\begin{array}{l}\text { Organic } \\
\text { C }\end{array}$ & $\begin{array}{l}\text { Total } \\
\mathbf{N}\end{array}$ & \multicolumn{2}{|c|}{ Mineral N $\left(\mathrm{kg} \mathrm{ha}^{-1}\right)$} & \multirow{2}{*}{\begin{tabular}{|l}
$\begin{array}{l}\text { Available } \\
\mathrm{K}\end{array}$ \\
$\left(\mathrm{kg} \mathrm{ha}^{-1}\right)$ \\
\end{tabular}} & \multirow{2}{*}{$\begin{array}{l}\text { Available } \\
\text { P } \\
\left(\mathrm{kg} \mathrm{ha}^{-1}\right)\end{array}$} & \multirow[b]{2}{*}{ pH } \\
\hline & & & \multicolumn{2}{|c|}{$\left(\mathrm{Mg} \mathrm{ha}^{-1}\right)$} & $\mathrm{NO}_{3}-\mathrm{N}$ & $\mathrm{NH}_{4}-\mathrm{N}$ & & & \\
\hline \multirow{2}{*}{2012} & $0-20$ & 1.48 & 31 & 2.4 & 46 & 14.5 & 527 & 93 & 7.4 \\
\hline & $20-40$ & 1.36 & 26 & 2.2 & 41 & 13.2 & 349 & 77 & 7.7 \\
\hline \multirow{2}{*}{2013} & $0-20$ & 1.43 & 30 & 2.6 & 46 & 13.6 & 524 & 77 & 7.4 \\
\hline & $20-40$ & 1.40 & 28 & 2.2 & 40 & 12.9 & 407 & 60 & 7.7 \\
\hline \multirow{2}{*}{2014} & $0-20$ & 1.41 & 29 & 2.2 & 43 & 12.7 & 506 & 74 & 7.4 \\
\hline & $20-40$ & \begin{tabular}{|l|}
1.57 \\
\end{tabular} & 28 & 2.1 & 41 & 12.2 & 379 & 67 & 7.7 \\
\hline
\end{tabular}

Table 5. Bulk density and chemical properties of the $0-20 \mathrm{~cm}$ and $20-40 \mathrm{~cm}$ soil layers sampled from the experimental field at planting and before fertilizer application in 2012, 2013, and 2014.

compensated for the loss of grain yield of intercropped pea. Total grain yield and biomass of maize/pea intercropping were increased as maize plant density increased.

\section{Conclusions}

In conclusion, maize/pea intercropping increases land productivity and NUE than sole cropping. The balance between $\mathrm{N}$ supply (with high $\mathrm{N}$ fertilizer application) and crop demand was improved with the D3 treatment in maize/pea intercropping. Increasing maize plant density enhanced crop $\mathrm{N}$ demand and decreased the soil mineral $\mathrm{N}$ at harvest, which reduced potential losses of soil $\mathrm{N}$. Overall, increased maize density is recommended to improve the quantitative synchrony between crop $\mathrm{N}$ demand and $\mathrm{N}$ supply, thus increasing productivity and NUE of maize/pea intercropping. Further research should be aimed at enhancing the temporal synchrony, as well as quantitative synchrony between $\mathrm{N}$ supply and crop demand in order to improve use of $\mathrm{N}$ resources and enhance environmental sustainability.

\section{Materials and Methods}

Experimental site. A field experiment was conducted in 2012, 2013, and 2014 at the Oasis Agricultural Experiment Station $\left(37^{\circ} 30^{\prime} \mathrm{N}, 103^{\circ} 5^{\prime} \mathrm{E} ; 1776 \mathrm{~m}\right.$ a.s.l.) of Gansu Agricultural University, located in Wuwei, Gansu Province of northwestern China. The experimental site is located in the temperate arid zone of the Eurasian continent. At this site, the long-term (1950-2014) average annual air temperature is $7.2^{\circ} \mathrm{C}$, with an accumulated air temperature above $10^{\circ} \mathrm{C}$ of $2985^{\circ} \mathrm{C}$. Annual precipitation is rarely greater than $155 \mathrm{~mm}$, mainly occurring from June to September, and potential evaporation is $2400 \mathrm{~mm}$. Weather conditions for the three experimental years were near the recent 10-year (2005-2014) average (Fig. 7). The soil at the experimental site is a calcareous Aridisol $^{44}$. The initial main chemical properties of the $0-20$ and $20-40 \mathrm{~cm}$ soil layers at the experimental site are shown in Table 5. Bulk density samples were collected from three randomly selected locations in each plot using a steel corer (with a volume of $98.12 \mathrm{~cm}^{3}$ ). Soil organic carbon was measured by the Walkley and Black dichromate oxidation method ${ }^{45}$. Total $\mathrm{N}$ concentration of soil samples was measured by the dry combustion method using a high-induction furnace $\mathrm{C}$ and $\mathrm{N}$ analyzer (Elementar vario MACRO cube, Germany). Exchangeable ammonium-nitrogen $\left(\mathrm{NH}_{4}-\mathrm{N}\right)$ and extractable nitrate-nitrogen $\left(\mathrm{NO}_{3}-\mathrm{N}\right)$ concentrations in the soil were analyzed by a continuous flow analyzer (Autoanalyzer 3, Bran-Luebbe, Germany). Available potassium (K) and phosphorus $(\mathrm{P})$ in the soil were measured according to Zhou et al. ${ }^{46}$. The content of soil organic $\mathrm{C}$, total $\mathrm{N}$, mineral $\mathrm{N}$ $\left(\mathrm{NH}_{4}-\mathrm{N}+\mathrm{NO}_{3}-\mathrm{N}\right)$, available $\mathrm{K}$, and available $\mathrm{P}$ was calculated as the product of their concentration and the respective bulk density and thickness for a given soil layer. Soil $\mathrm{pH}$ was measured in a 1:2 (m:v) soil solution with $0.01 \mathrm{~mol} \mathrm{~L}^{-1} \mathrm{CaCl}_{2}$, using a $\mathrm{pH}$ meter (Orion, Thermo Fisher Scientific Inc., Waltham, MA, USA) ${ }^{47}$.

Experimental design. The experimental design was a randomized complete block with three replications. Maize was planted in 2011 prior to this experiment. The treatments were applied to the same plots in each year. 


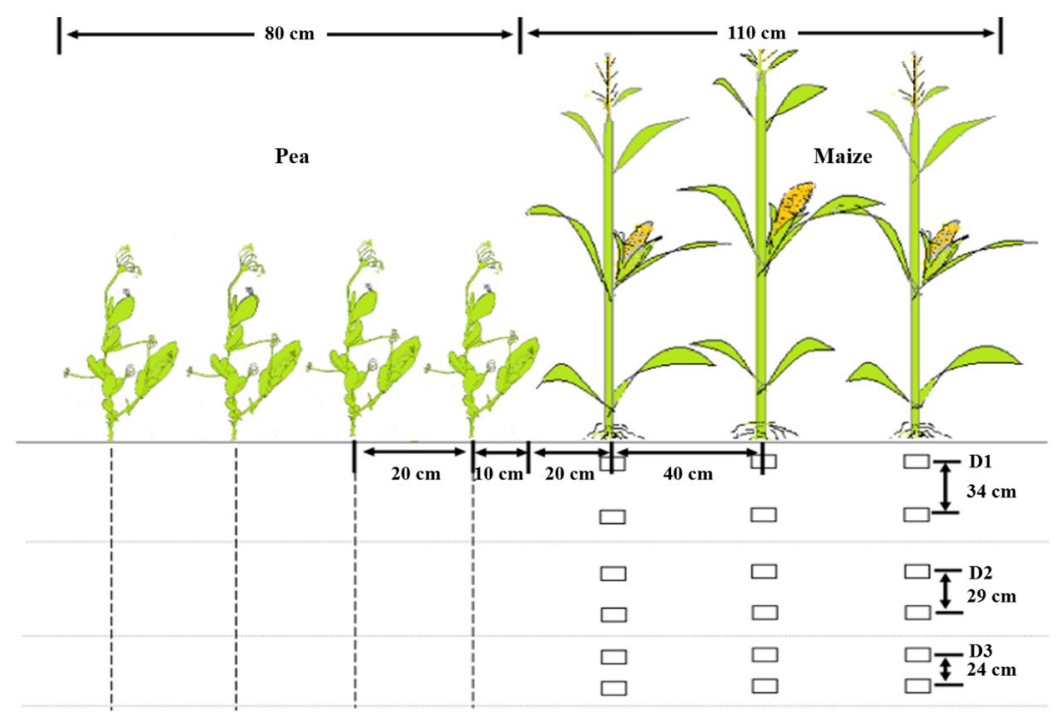

Figure 8. Strip structure of maize/pea intercropping and field locations where soil samples were collected annually. Each maize strip ( $110 \mathrm{~cm}$ wide) consisted of three rows of maize spaced $40 \mathrm{~cm}$ apart, and each pea strip ( $80 \mathrm{~cm}$ wide) consisted of four rows of pea spaced $20 \mathrm{~cm}$ apart. Sole maize treatments included three plant densities controlled by interplant distance: D1 at 73,600 plants ha ${ }^{-1}, \mathrm{D} 2$ at 85,900 plants ha ${ }^{-1}$, and D3 at 98,200 plants $\mathrm{ha}^{-1}$; the relative density of intercropped maize (according to the proportion of occupied area in intercropping) was 45,000,52,500, and 60,000 plants ha ${ }^{-1}$ for D1, D2, and D3, respectively.

\begin{tabular}{|c|c|c|c|c|c|c|}
\hline \multirow[b]{2}{*}{ Treatment } & $\begin{array}{l}\text { Maize } \\
\text { 2-leaf stage }\end{array}$ & $\begin{array}{l}\text { Maize } \\
\text { 6-leaf stage }\end{array}$ & $\begin{array}{l}\text { Maize } \\
\text { 12-leaf stage }\end{array}$ & $\begin{array}{l}\text { Maize } \\
\text { silking stage }\end{array}$ & $\begin{array}{l}\text { Maize Kernel } \\
\text { milk stage }\end{array}$ & $\begin{array}{l}\text { Irrigation } \\
\text { total }\end{array}$ \\
\hline & \multicolumn{6}{|l|}{$\mathrm{mm}$} \\
\hline Sole pea & 90 & 120 & - & - & - & 210 \\
\hline Sole maize & 90 & 120 & 120 & 120 & 90 & 540 \\
\hline Intercropping & 90 & 120 & 120 & 120 & 90 & 540 \\
\hline
\end{tabular}

Table 6. Irrigation schedule and amounts of water applied to the cropping system treatments in this experiment in each of the three years. The irrigation schedule is based on maize phenological development ${ }^{48}$.

Three cropping systems (sole maize, sole pea, and maize/pea intercropping), three maize densities, and two $\mathrm{N}$ application rates were investigated. The intercropping was a replacement design. Maize density varied and a constant pea density was used in the intercropping system. The three sole maize densities were 73,600, 85,900, and 98,200 plants ha ${ }^{-1}$ for D1, D2, and D3, respectively. According to the occupied area proportions (occupied area proportions of maize and pea were $58 \%$ and $42 \%$, respectively), the relative density of intercropped maize was $58 \%$ of sole maize. The densities of intercropped maize were $45,000,52,500$, and 60,000 plants ha ${ }^{-1}$ for D1, D2, and D3, respectively. The density of sole pea was 900,000 plants ha ${ }^{-1}$, and that of intercropped pea was 380,000 plants $\mathrm{ha}^{-1}$. Therefore, maize in intercropping and sole cropping had equal densities of pure occupied area. The two $\mathrm{N}$ treatments were N0 $\left(0 \mathrm{~kg} \mathrm{~N} \mathrm{ha}^{-1}\right.$ for maize and pea) and $\mathrm{N} 1\left(450 \mathrm{~kg} \mathrm{~N} \mathrm{ha}^{-1}\right.$ for maize and $225 \mathrm{~kg} \mathrm{~N} \mathrm{ha}^{-1}$ for pea). For the $\mathrm{N} 1$ treatment, $225 \mathrm{~kg} \mathrm{~N} \mathrm{ha}^{-1}$ as ammonium nitrate was broadcast and incorporated into the top $20 \mathrm{~cm}$ of the soil as a base fertilizer prior to the planting maize and pea. Then, $112.5 \mathrm{~kg} \mathrm{~N} \mathrm{ha}^{-1}$ as urea was top-dressed at both the 6- and 12-leaf stages of maize phenological development ${ }^{48}$.

In the intercropping treatment, one strip ( $1.9 \mathrm{~m}$ wide) included three maize rows and four pea rows, and one plot contained three strips (Fig. 8). The inter-row spacing was $40 \mathrm{~cm}$ for maize and $20 \mathrm{~cm}$ for pea, and the distance between the maize row and the nearest pea row was $0.30 \mathrm{~m}$ in the intercropping treatment. All plots were $8 \mathrm{~m} \times 5.7 \mathrm{~m}$, with a $0.5 \mathrm{~m}$ wide ridge surrounding each plot. The dates of planting were 1 Apr. 2012, 2 Apr. 2013, and 1 Apr. 2014 for pea (cultivar Long-wan no.1) and 21 Apr. 2012, 22 Apr. 2013, and 20 Apr. 2014 for maize (cultivar Xian-yu 335). All plots received $150 \mathrm{~kg} \mathrm{P}_{2} \mathrm{O}_{5} \mathrm{ha}^{-1}$ prior to planting at the time of the first $\mathrm{N}$ application, using calcium superphosphate $\left(0-16-0\right.$ of $\left.N-\mathrm{P}_{2} \mathrm{O}_{5}-\mathrm{K}_{2} \mathrm{O}\right)$. Irrigation was applied to all plots during the growing season to prevent water stress (Table 6). Irrigation was applied using pipes (13 cm diameter), and a water meter installed at the discharging end of the pipe was used to determine the amount of water applied.

Sample collection and analysis. Soil samples were collected from the $0-20,20-40,40-60,60-90$, and $90-120 \mathrm{~cm}$ soil layers before planting and at harvest of pea or maize using a soil drill made of an iron tube $(150 \mathrm{~cm}$ length $\times 6.5 \mathrm{~cm}$ internal diameter $\times 7.0 \mathrm{~cm}$ external diameter). During the growing season, soil samples were collected every $15 \mathrm{~d}$ before harvest of pea and every $20 \mathrm{~d}$ from pea harvest to maize harvest; samples were divided into $0-20$ and $20-40 \mathrm{~cm}$ depth increments. Four soil cores were collected from the intercropping system (Fig. 2) 
and mixed thoroughly to obtain a composite sample. Two cores were obtained from pea rows and two cores were obtained from maize rows. For the sole crop treatments, two soil cores were collected from each plot and mixed thoroughly. Soil cores were passed through a $2 \mathrm{~mm}$ sieve and then extracted with $100 \mathrm{~mL}$ of $0.01 \mathrm{~mol} \mathrm{~L}^{-1} \mathrm{CaCl}_{2}$ to determine soil mineral $\mathrm{N}\left(\mathrm{NH}_{4}-\mathrm{N}\right.$ and $\left.\mathrm{NO}_{3}-\mathrm{N}\right)$ concentration using a continuous flow analyzer (Autoanalyzer 3, Bran-Luebbe, Germany).

Ten maize plants and four adjacent rows of pea, with row lengths of $50 \mathrm{~cm}$, were sampled from each plot. Plant samples were collected every $15 \mathrm{~d}$ before pea harvest and every $20 \mathrm{~d}$ from pea harvest to maize harvest. Maize and pea biomass were measured by oven drying samples at $80^{\circ} \mathrm{C}$ to a constant mass and weighing. Maize and pea plant samples were milled after oven drying for analysis of $\mathrm{N}$ and $\delta^{15} \mathrm{~N}$. Nitrogen concentration in plant biomass was determined by a high-induction furnace $\mathrm{C}$ and $\mathrm{N}$ analyzer (Elementar vario MACRO cube, Germany) after oven drying and grinding to $1 \mathrm{~mm}$. Mass spectrometry (DELTAplus XP, Thermo Finnigan, Bremen, Germany) was used to determine $\delta^{15} \mathrm{~N}$. At crop physiological maturity, plots were harvested by hand and the harvested grain was air-dried, cleaned, and weighed to determine grain yield.

Calculations. During the growing season, mineral $\mathrm{N}\left(\mathrm{NO}_{3}-\mathrm{N}\right.$ and $\left.\mathrm{NH}_{4}-\mathrm{N}\right)$ in the $0-20 \mathrm{~cm}$ and $20-40 \mathrm{~cm}$ soil layers was calculated as the product of bulk density and concentration of soil $\mathrm{NO}_{3}{ }^{-} \mathrm{N}$ or $\mathrm{NH}_{4}{ }^{+}-\mathrm{N}$. At planting and harvest of pea and maize, mineral $\mathrm{N}$ in the soil profile $(0-120 \mathrm{~cm})$ was also calculated as:

$$
\mathrm{Y}=\Sigma \mathrm{T}_{\mathrm{i}} \mathrm{BD}_{\mathrm{i}}\left[\mathrm{NO}_{3}^{-}\right]_{\mathrm{i}}+\Sigma \mathrm{T}_{\mathrm{i}} \mathrm{BD}_{\mathrm{i}}\left[\mathrm{NH}_{4}^{+}\right]_{\mathrm{i}}
$$

where $\mathrm{T}_{\mathrm{i}}, \mathrm{BDi},\left[\mathrm{NO}_{3}{ }^{-}\right]_{\mathrm{i}}$, and $\left[\mathrm{NH}_{4}{ }^{+}\right]_{\mathrm{i}}$ are the thickness, bulk density, and concentration of soil $\mathrm{NO}_{3}{ }^{-}$and $\mathrm{NH}_{4}{ }^{+}$in a given soil layer, respectively ${ }^{49}$.

The percentage of total aboveground $\mathrm{N}$ accumulation for pea, derived from $\mathrm{N}_{2}$-fixation $\left(\% \mathrm{~N}_{\mathrm{dfa}}\right)$, was calculated using the ${ }^{15} \mathrm{~N}$ content of pea $\left(\delta^{15} \mathrm{~N}_{\text {pea }}\right)$ and maize $\left(\delta^{15} \mathrm{~N}_{\text {maize }}\right)$ :

$$
\% \mathrm{~N}_{\mathrm{dfa}}=100 \times \frac{\delta^{15} \mathrm{~N}_{\text {maize }}-\delta^{15} \mathrm{~N}_{\text {pea }}}{\delta^{15} \mathrm{~N}_{\text {maize }}-\mathrm{B}}
$$

where $\delta^{15} \mathrm{~N}_{\text {pea }}$ and $\delta^{15} \mathrm{~N}_{\text {maize }}$ represent $\delta^{15} \mathrm{~N}\left(\%\right.$ ) values of pea and maize growing in the same field. The $\delta^{15} \mathrm{~N}(\%)$ values were calculated based on the ${ }^{15} \mathrm{~N}$ natural abundance method ${ }^{50}$. The $\mathrm{B}$ value for pea $(-1.05)$ was derived from $\delta^{15} \mathrm{~N}$ natural abundance analysis of pea grown with $\mathrm{N}$-free sand ${ }^{49}$. $(\% \mathrm{~N})$ :

Crop $\mathrm{N}$ derived from the atmosphere $\left(\mathrm{N}_{\mathrm{dfa}}\right)$ was calculated based on crop biomass yield and $\mathrm{N}$ concentration

$$
\mathrm{N}_{\mathrm{dfa}}=\text { Biomass } \times \% \mathrm{~N} \times\left(\frac{\% \mathrm{Ndfa}}{100}\right)
$$

Nitrogen accumulation by crops was calculated as the product of biomass and $\mathrm{N}$ content.

The $\Delta \mathrm{N}$ was used to determine the balance between crop $\mathrm{N}$ demand and $\mathrm{N}$ supply during the growing season:

$$
\Delta N=\mathrm{N}_{\text {accumulation }}-\left(\mathrm{N}_{\text {planting }}+\mathrm{N}_{\text {fertilizer }}-\mathrm{N}_{\text {harvest }}\right)
$$

where $\Delta \mathrm{N}$ is the balance between crop $\mathrm{N}$ demand and $\mathrm{N}$ supply during the growing season, $\mathrm{N}_{\text {accumulation }}$ is the total aboveground $\mathrm{N}$ accumulation in plants, $\mathrm{N}_{\text {planting }}$ and $\mathrm{N}_{\text {harvest }}$ are soil $\mathrm{N}$ measured at planting and harvest, respectively, and $\mathrm{N}_{\text {fertilizer }}$ is $\mathrm{N}$ derived from fertilizer applied during the growing season. A $\Delta \mathrm{N}$ of zero indicates that $\mathrm{N}$ demand of the cropping system ( $\mathrm{N}$ accumulation in crops) was equal to $\mathrm{N}$ supply (residual soil $\mathrm{N}$ at planting plus fertilizer $\mathrm{N}$, minus residual soil $\mathrm{N}$ at crop harvest). A positive $\Delta \mathrm{N}$ indicates that $\mathrm{N}$ demand of the cropping system exceeded the $\mathrm{N}$ supply and that some $\mathrm{N}$ may be from soil $\mathrm{N}$ mineralization or $\mathrm{N}_{2}$ fixation. A negative $\Delta \mathrm{N}$ indicates that $\mathrm{N}$ demand of the cropping system was less than $\mathrm{N}$ supply and that excess $\mathrm{N}$ may be susceptible to loss through leaching, denitrification, or ammonia volatilization.

The total land equivalent ratio (LER) was used to evaluate the relative advantage of intercropping compared to sole cropping ${ }^{51}$. This index expresses the land area required under sole cropping to produce the yields obtained in intercropping. The $\mathrm{N}$ equivalent ratio (NER), LER for grain yield $\left(\mathrm{LER}_{\text {grain }}\right)$, and biomass $\left(\mathrm{LER}_{\mathrm{biomass}}\right)$ for intercropping of pea and maize were calculated according to Rao and Willey ${ }^{51}$. Total LER is the sum of partial NER and LER values for pea and maize: $\mathrm{NER}_{\text {pea }}$ or $\mathrm{LER}_{\text {pea }}=\left(\mathrm{Y}_{\mathrm{IP}} \times \mathrm{A}_{\mathrm{P}}\right) / \mathrm{Y}_{\mathrm{SB}} \mathrm{NER}_{\text {maize }}$ or $\mathrm{LER}_{\text {maize }}=\left(\mathrm{Y}_{\mathrm{IM}} \times \mathrm{A}_{\mathrm{M}}\right) / \mathrm{Y}_{\mathrm{SM}}$, total $\mathrm{NER}$ or LER $=\mathrm{LER}_{\text {pea }}+\mathrm{LER}_{\text {maize, }}$, where $\mathrm{Y}_{\mathrm{IP}}$ and $\mathrm{Y}_{\mathrm{SP}}$ are $\mathrm{N}$ accumulation, grain yield, or biomass of intercropped pea and sole pea, respectively, $\mathrm{Y}_{\mathrm{IM}}$ and $\mathrm{Y}_{\mathrm{SM}}$ are $\mathrm{N}$ accumulation, grain yield, or biomass of intercropped maize and sole maize, respectively, and $\mathrm{A}_{\mathrm{P}}$ and $\mathrm{A}_{\mathrm{M}}$ are the ratios of area occupied by pea and maize in the intercropping system relative to that of the corresponding sole cropping systems, respectively.

Apparent $\mathrm{N}$ use efficiency (NUE) from treatments with $\mathrm{N}$ applied was calculated according to Dalal et al..$^{52}$ :

$$
\mathrm{NUE}(\%)=100 \times \frac{\mathrm{N} \text { uptake from } \mathrm{N} \text { treatment }-\mathrm{N} \text { uptake from control }}{\mathrm{N} \text { applied }}
$$

Statistical analysis. Statistical analysis was conducted at $P \leq 0.05$ using the SPSS software package (version 19.0, SPSS, Chicago, USA). The year $\times$ treatment interaction and the main effects of year and treatment were assessed using ANOVA. When a significant year $\times$ treatment interaction was not observed, the three years of data were pooled for mean comparisons. Means were compared using Fisher's protected LSD test at $P \leq 0.05$. 


\section{References}

1. Wienhold, B. J., Trooien, T. P. \& Reichman, G. A. Yield and nitrogen use efficiency of irrigated corn in the northern Great Plains. Agronomy journal 87, 842-846 (1995).

2. Plaza-Bonilla, D., Nolot, J. M., Raffaillac, D. \& Justes, E. Innovative cropping systems to reduce $\mathrm{n}$ inputs and maintain wheat yields by inserting grain legumes and cover crops in southwestern france. European Journal of Agronomy 82, 331-341 (2016).

3. Vitousek, P. M. et al. Human alteration of the global nitrogen cycle: sources and consequences. Ecological Applications 7, 737 (1997).

4. Peoples, M. B. et al. The contributions of nitrogen-fixing crop legumes to the productivity of agricultural systems. Symbiosis 48, 1-17 (2009).

5. Herridge, D. F., Peoples, M. B. \& Boddey, R. M. Global inputs of biological nitrogen fixation in agricultural systems. Plant and Soil 311, 1-18 (2008).

6. Crews, T. E. \& Peoples, M. B. Can the synchrony of nitrogen supply and crop demand be improved in legume and fertilizer-based agroecosystems? A review. Nutrient Cycling in Agroecosystems 72, 101-120 (2005).

7. Yang, W., Li, Z., Wang, J., Wu, P. \& Zhang, Y. Crop yield, nitrogen acquisition and sugarcane quality as affected by interspecific competition and nitrogen application. Field Crops Research 146, 44-50 (2013).

8. Alain, R., Paula, F., Jacques, A. \& Robert, H. Plant species diversity for sustainable management of crop pests and diseases in agroecosystems: a review. Agronomy for Sustainable Development 32, 273-303 (2012).

9. Carruthers, K. et al. Intercropping corn with soybean, lupin and forage: Yield component responses. European Journal of Agronomy 12, 103-115 (2000)

10. Chen, X. P. et al. Integrated soil-crop system management for food security. Proceedings of the National Academy of Sciences 108, 6399-6404 (2011).

11. Chen, P. et al. Effects of reduced nitrogen inputs on crop yield and nitrogen use efficiency in a long-term maize-soybean relay strip intercropping system. Plos One 12, e0184503 (2017).

12. Li, Q. Z. et al. Overyielding and interspecific interactions mediated by nitrogen fertilization in strip intercropping of maize with faba bean, wheat and barley. Plant and Soil 339, 147-161 (2011).

13. Erisman, J. W., Sutton, M. A., Galloway, J., Klimont, Z. \& Winiwarter, W. How a century of ammonia synthesis changed the world. Nature Geoscience 1, 636-639 (2008).

14. Smil, V. Nitrogen in crop production: An account of global flows. Global Biogeochemical Cycles 13, 647-662 (1999).

15. Cassman, K. G., Gines, G. C., Dizon, M. A., Samson, M. I. \& Alcantara, J. M. Nitrogen-use efficiency in tropical lowland rice systems: contributions from indigenous and applied nitrogen. Field Crops Research 47, 1-12 (1996).

16. Lobell, D. B. The cost of uncertainty for nitrogen fertilizer management: A sensitivity analysis. Field Crops Research 100, 210-217 (2007).

17. Hu, F. et al. Improving $\mathrm{N}$ management through intercropping alleviates the inhibitory effect of mineral $\mathrm{N}$ on nodulation in pea. Plant and Soil 412, 235-251 (2017).

18. Ananthi, T. \& Amanullah, M. M. A review on maize-legume intercropping for enhancing the productivity and soil fertility for sustainable agriculture. Advances in Environmental Biology 11, 49-63 (2017).

19. Anil, L., Park, R. H. P. \& Miller, F. A. Temperate intercropping of cereals for forage: a review of the potential for growth and utilization with particular reference to the UK. Grass \& Forage Science 53, 301-317 (1998).

20. Carruthers, K. et al. Intercropping corn with soybean, lupin and forages: yield component responses. European Journal of Agronomy 12, 103-115(2000).

21. Jensen, E. S. Barley uptake of N deposited in the rhizosphere of associated field pea. Soil Biology \& Biochemistry 28, 159-168 (1996).

22. Echarte, L. et al. Yield response to plant density of maize and sunflower intercropped with soybean. Field Crops Research 121, 423-429 (2011)

23. Corre-Hellou, G., Brisson, N., Launay, M., Fustec, J. \& Crozat, Y. Effect of root depth penetration on soil nitrogen competitive interactions and dry matter production in pea-barley intercrops given different soil nitrogen supplies. Field Crops Research 103, $76-85$ (2007).

24. Zhang, F. \& Li, L. Using competitive and facilitative interactions in intercropping systems enhances crop productivity and nutrientuse efficiency. Plant and Soil 248, 305-312 (2003).

25. Rejmanek, M., Robinson, G. R. \& Rejmankova, E. Weed-crop competition: experimental designs and models for data analysis. Weed Science 37, 276-284 (1989).

26. Dhamala, N. R., Rasmussen, J., Carlsson, G., Søegaard, K. \& Eriksen, J. N transfer in three-species grass-clover mixtures with chicory, ribwort plantain or caraway. Plant and Soil 413, 217-230 (2017).

27. Liu, M., Qiao, N., Zhang, Q. \& Xu, X. L. Cropping regimes affect NO3- versus NH4+ uptake by Zea mays and Glycine max. Plant and Soil 426, 241-251 (2018).

28. Danso, S. K. A., Zapata, F., Hardarson, G. \& Fried, M. Nitrogen fixation in fababeans as affected by plant population density in sole or intercropped systems with barley. Soil Biology \& Biochemistry 19, 411-415 (1987).

29. Li, Y. Y. et al. Intercropping alleviates the inhibitory effect of $\mathrm{N}$ fertilization on nodulation and symbiotic $\mathrm{N}_{2}$ fixation of faba bean. Plant and Soil 323, 295-308 (2009).

30. Fan, F. et al. Nitrogen fixation of faba bean (Vicia faba L.) interacting with a non-legume in two contrasting intercropping systems. Plant and Soil 283, 275-286 (2006).

31. Robertson G. P. Nitrogen use efficiency in row-crop agriculture: crop nitrogen use and soil nitrogen loss. In: Jackson, L. (ed.), Ecology in Agriculture. Academic Press, San Diego pp. 347-365 (1997).

32. Campbell, C. A., Myers, R. J. K. \& Curtin, D. Managing nitrogen for sustainable crop production. Fertilizer Research 42, 277-296 (1995).

33. Correhellou, G., Fustec, J. \& Crozat, Y. Interspecific competition for soil $\mathrm{N}$ and its interaction with $\mathrm{N}_{2}$ fixation, leaf expansion and crop growth in pea-barley intercrops. Plant and Soil 282, 195-208 (2006).

34. Yang, F. et al. Effect of aboveground and belowground interactions on the intercrop yields in maize-soybean relay intercropping systems. Field Crops Research 203, 16-23 (2017).

35. Banik, P. \& Sharma, R. C. Yield and resource utilization efficiency in baby corn-legume-intercropping system in the eastern plateau of India. Journal of Sustainable Agriculture 33, 379-395 (2009).

36. Chapagain, T. \& Riseman, A. Barley-pea intercropping: effects on land productivity, carbon and nitrogen transformations. Field Crops Research 166, 18-25 (2014).

37. Hamzei, J. \& Seyedi, M. Evaluation of the effects of intercropping Systems on yield performance, land equivalent ratio, and weed control efficiency. Agricultural Research 4, 202-207 (2015).

38. Ndakidemi, P. \& Dakora, F. Changes in $\delta^{15} \mathrm{~N}$ and $\mathrm{N}$ nutrition in nodulated cowpea (Vigna unguiculata (L.) Walp.) and maize (Zea mays L.) grown in mixed culture with exogenous P supply. Springer Netherlands, 617-630 (2011).

39. Ndungu-Magiroi, K. W. et al. Maize-bean intercrop response to nutrient application relative to maize sole crop response. Nutrient Cycling in Agroecosystems 109, 17-27 (2017).

40. Dong, H., Kong, X., Li, W., Tang, W. \& Zhang, D. Effects of plant density and nitrogen and potassium fertilization on cotton yield and uptake of major nutrients in two fields with varying fertility. Field Crops Research 119, 106-113 (2010).

41. Lambers, H., Chapin, F. S. \& Pons, T. L. Plant physiological ecology. Springer-Verlag, New York (1998). 
42. Aminifar, J. \& Ghanbari, A. Biological facilitative interactions and their roles on maximize growth and productivity of crops in intercropping systems. Scientia Agriculturae 2, 90-95 (2014).

43. Hauser, S., Norgrove, L. \& Nkem, J. N. Groundnut/maize/cassava intercrop yield response to fallow age, cropping frequency and crop plant density on an ultisol in southern cameroon. Biological Agriculture and Horticulture 24, 275-291 (2016).

44. FAO/UNESCO. Soil map of the world: revised legend/prepared by the Food and Agriculture Organization of the United Nations. Unesco (1988).

45. Nelson, D. W. \& Sommers, L. E. Total carbon, organic carbon and organic matter, In: Page, A. L., Miller, R. H., Keeney, D. R. (Eds.), Methods of soil analysis. Part 2. Chemical and microbiological properties, second ed. Agronomy Monograph No. 9. American Society of Agronomy Inc., Madison, WI, pp. 539-577 (1982).

46. Zhou, S. H. I., Wang, K. E. \& Bailey, J. S. Sampling strategies for soil available K and P at field scale. Pedosphere 10, 309-315 (2000).

47. Kalra, Y. P. \& Maynard, D. G. Methods manual for forest soil and plant analysis. Forestry Canada, Northwest Region. Northern Forestry Centre, Alberta. For Can, Northwest (1991).

48. Abendroth, L. J., Elmore, R.W., Boyer, M. J. \& Marlay, S. K. Corn Growth and Development. PMR 1009. Iowa State University Extension. Ames Iowa (2011).

49. Yu, C. B. et al. An improved nitrogen difference method for estimating biological nitrogen fixation in legume-based intercropping systems. Biology \& Fertility of Soils 46, 227-235 (2010).

50. Shearer, G. \& Kohl, D. H. $\mathrm{N}_{2}$-fixation in field settings: estimations based on natural ${ }^{15} \mathrm{~N}$ abundance. Functional Plant Biology 13 , 699-756 (1986).

51. Rao, M. R. \& Willey, R. W. Evaluation of yield stability in intercropping: studies on sorghum/pigeonpea. Experimental Agriculture 16, 105-116 (1980).

52. Dalal, R. C., Strong, W. M., Cooper, J. E. \& King, A. J. Relationship between water use and nitrogen use efficiency discerned by ${ }^{13} \mathrm{C}$ discrimination and ${ }^{15} \mathrm{~N}$ isotope ratio in bread wheat grown under no-till. Soil \& Tillage Research 128, 110-118 (2013).

\section{Acknowledgements}

This study was supported by the Gansu Provincial Key Laboratory of Aridland Crop Science, Gansu Agricultural University (No. GSCS-2017-5), Special Fund for Talents of Gansu Agricultural University (GAU-RCZX-201705), the Modern Agro-Industry Technology Research System (Grant CARS-22-G-12), and the National Natural Science Fund (Grants 31771738 and 31160265).

\section{Author Contributions}

Qiang Chai, Weidong Cao and Zhilong Fan, contributed conception and design of the study; Zhilong Fan and Yanhua Zhao organized the database; Zhilong Fan performed the statistical analysis; Zhilong Fan, Qiang Chai, Jeffrey A. Coulter and Yantai Gan wrote the first draft of the manuscript; Cai Zhao and Aizhong Yu wrote sections of the manuscript; all authors contributed to manuscript revision, read and approved the submitted version.

\section{Additional Information}

Competing Interests: The authors declare no competing interests.

Publisher's note: Springer Nature remains neutral with regard to jurisdictional claims in published maps and institutional affiliations.

(c) (i) Open Access This article is licensed under a Creative Commons Attribution 4.0 International License, which permits use, sharing, adaptation, distribution and reproduction in any medium or format, as long as you give appropriate credit to the original author(s) and the source, provide a link to the Creative Commons license, and indicate if changes were made. The images or other third party material in this article are included in the article's Creative Commons license, unless indicated otherwise in a credit line to the material. If material is not included in the article's Creative Commons license and your intended use is not permitted by statutory regulation or exceeds the permitted use, you will need to obtain permission directly from the copyright holder. To view a copy of this license, visit http://creativecommons.org/licenses/by/4.0/.

(C) The Author(s) 2019 